\title{
ŠTO ZNAČI POJAM GOVERNANCE I KAKO GA TREBA PREVODITI?
}

Prof. dr. sc. Gojko Bežovan*

UDK: $35.07 .01: 81^{`} 25$

$328.185 .01: 81 ` 25$

DOI: 10.3935/zpfz.71.5.03

Pregledni znanstveni rad

Primljeno: rujan 2021.

Tekst analizira značenje i razumijevanje pojma governance te njegov prijevod na hrvatski jezik. Vlade, izvršne vlasti, vladajući (governing) pristupom odozgo, izdavanjem naloga $i$ kontroliranjem, odnosno upravljanjem, ne mogu se učinkovito $i$ djelotvorno nositi s problemima i izazovima. Kako bi odgovorile na takve izazove, vlade prihvaćaju vladanje odozdo, po horizontalnom načelu suradnje s ostalim dionicima, pa su onda u prilici mobilizirati raspoložive resurse, izgraditi povjerenje i novu mrežu suradnje te razviti koncept vladavine (governance). Koncept dobre vladavine u Europskoj uniji je alat kojim se jačaju procesi konvergencije. Istraživanja o vladavini u Hrvatskoj su rijetka, a radovi o toj temi uglavnom analiziraju vladavinu, dobru vladavinu i višerazinsku vladavinu kao novu upravnu doktrinu. Imajući $u$ vidu značenje pojma governance $u$ engleskom jeziku te njegovo značenje u odnosu na druge pojmove, drži se da ga na hrvatski jezik treba prevoditi kao vladavina. Analizira se i značenje pojmova: affordability, social entrepreneurship, eligibility $i$ resilience te se predlaže prevođenje na hrvatski jezik.

Ključne riječi: governance, vladavina, upravljanje, dobra vladavina, prevodenje na hrvatski

* Dr. sc. Gojko Bežovan, profesor Pravnog fakulteta Sveučilišta u Zagrebu, Trg Republike Hrvatske 14, 10000 Zagreb; gojko.bezovan@pravo.hr;

ORCID ID: orcid.org/0000-0002-7543-6875 


\section{UVOD}

U tekstu se analiziraju izazovi prevođenja, značenja i razumijevanja više važnih pojmova koji su osobito došli na dnevni red našim pristupanjem Europskoj uniji. ${ }^{1}$ Glavna tema je pojam governance koji se u službenim dokumentima prevodi kao upravljanje, što slijedi i veći dio akademske zajednice. ${ }^{2}$ To više, governance je tema istraživanja, a i novih nastavnih sadržaja u visokoškolskoj nastavi. Rad tematizira i kontekst promicanja koncepta governance u EU-u. Ističe se i njegova naglašenost u novoj razvojnoj perspektivi 2021. - 2027. Europske unije, u kojoj se jačanje koncepta governance dijelom vidi kao odgovor na rastuće izazove u svim razvojnim područjima.

Koncept governance pripada interdisciplinarnom području istraživanja. Glede značenja i razumijevanja pojma governance u radu se ostvaruje uvid u literaturu koja je pretežito povezana uz širi koncept socijalne politike te razvoj civilnog društva, kao i u istraživanja koja mogu pomoći u produbljivanju znanja, izazova i dosega ostvarivanja tog koncepta u praksi. ${ }^{3}$

1 Autor zahvaljuje na komentarima na prethodnu inačicu teksta kolegama izv. prof. dr. sc. Marku Aleriću, Odsjek za kroatistiku, Filozofski fakultet Sveučilišta u Zagrebu te doc. dr. sc. Jeleni Matančević i doc. dr. sc. Danijelu Baturini s Katedre za socijalnu politiku Pravnog fakulteta Sveučilišta u Zagrebu.

2 Ovaj rad nastao je u okviru projekta "SUSTINEO - Suradnjom, sudjelovanjem, istraživanjem i edukacijom za održivost", a prihvaćen je na natječaju Europskog socijalnog fonda Tematske mreže za društveno-ekonomski razvoj te promicanje socijalnog dijaloga u kontekstu unapređivanja uvjeta rada.

3 Autor teksta, zahvaljujući kolegi Frani Adamu s Ljubljanske Univerze, bio je aktivni suradnik u istraživanju Network of Excellence on "Efficient and Democratic Governance in a Multi-level Europe" (CONNEX), EU FP6 od 2004. do 2008. U okviru projekta objavljen je velik broj publikacija, https://www.mzes.uni-mannhe$\mathrm{im} . \mathrm{de} / \mathrm{d} 7 / \mathrm{en} / \mathrm{projects} /$ network-of-excellence-on-efficient-and-democratic-governance-in-a-multi-level-europe-connex (15. travnja 2021.). Edicija European Governance Papers dio je partnerstva s projektom NEWGOV. Autor je, informirajući akademsku javnost o ishodima projekta, upozorio na izazove prevođenja nekih pojmova, vidi: Bežovan, G., Final Conference of the Connex Network of Excellence: Efficient and Democratic Governance in a Multilevel Europe, Revija za socijalnu politiku, vol. 15, br. 2, 2008., str. 290 - 293. U okviru istog istraživačkog programa u tom vremenu provođen je i projekt "New Modes of Governance" - NEWGOV, http://www.eu-newgov. org/ (15. travnja 2021.). Autor je bio partner u EU FP7 projektu "Welfare Innovations at the Local Level in Favour of Cohesion" - WILCO, 2011. - 2014., a istraživane su i prakse lokalne socijalne i urbane vladavine, http://www.wilcoproject.eu/ (15. travnja 2021.). 
Vladavina kao koncept promiče se kroz programe Europske unije. U tekstu se analiziraju dokumenti koji produbljuju koncept vladavine te izazovi provedbe načela vladavine $\mathrm{u}$ konkretnim programima.

Empirijska istraživanja u ovom području u Hrvatskoj relativno su rijetka, a njihov djelomični presjek upućuje na tematske okvire i preporuke za razvoj koncepta vladavine. ${ }^{4}$ Upućuje se i u izazove prevođenja ovog pojma u drugim zemljama. Dakle, cilj rada uglavnom je ograničen na analizu značenja i razumijevanja pojma governance kako bi se predložio odgovarajući prijevod na hrvatski jezik. U tom kontekstu dijelom se analizira i koncept korporativne vladavine.

U tekstu se izlaže argumentacija prevođenja pojma governance pojmom vladavina, a ne pojmom upravljanje. Problem prevođenja i upotrebe pojma governance postavlja se kao semantički odnos koji znak ima prema stvarnom ili mogućemu predmetu u svijetu te odnos koji znak ima prema drugomu znaku. ${ }^{5}$ Upravljanje je predmet, odnosno društvena činjenica koja već dugo opisuje društveni ustroj, governance - vladavina društvena je činjenica povezana uz noviji razvoj i ustroj suverenih modernih društva. ${ }^{6} \mathrm{U}$ tom smislu važan je odnos vladavine kao znaka prema drugim znakovima, pa tako i prema upravljanju.

Ovu temu stavlja se i u kontekst jezične kulture ${ }^{7}$, koja traži pomnju nad punim i izvornim značenjem jezičnih izraza te njihovu vezu s drugim riječima. Jezična kultura za Katičića je etimologija, a to znači bavljenje izvornim i punim značenjem riječi.

K tome, ukratko se upozorava na izazove prevođenja i značenje pojmova affordability, social entrepreneurship, eligibility i resilience. Time se ističe potreba daljnjih istraživanja i rasprava o toj temi.

Uz prethodno istaknuti glavni cilj rada, dodatna njegova je svrha potaknuti dijalog u akademskoj zajednici i, koliko je to moguće, u stručnoj javnosti o izazovima prevođenja pojma governance, kao i drugih pojmova, te njihova značenja i razumijevanja.

4 Pri citiranju radova za governance se upotrebljava pojam iz rada, ako je rad na engleskom, upotrebljava se pojam vladavina.

5 Semantika, Hrvatska enciklopedija, mrežno izdanje, Leksikografski zavod Miroslav Krleža, 2021., https://www.enciklopedija.hr/natuknica.aspx?id=55330 (15. travnja 2021.).

6 Vidi više: Osborne, P. S., The New Public Governance?, Public Management Review, vol. 8, br. 3, 2006., str. $377-387$.

7 Vidi više: Katičić, R., Novi jezikoslovni ogledi, Školska knjiga, Zagreb, 1986., posebno str. $84-85$. 


\section{GOVERNANCE - ODREĐENJE POJMA, NJEGOVO ZNAČENJE I ISTRAŽIVANJE KONCEPTA}

Governance je tema rasprava u društvenim znanostima i definira se na različite načine. ${ }^{8}$ Novije rasprave upućuju kako koncept vladavine (governance) dolazi iz poslovnog svijeta. ${ }^{9}$ Ističe se kako struktura korporativne vladavine određuje raspodjelu prava i odgovornosti među različitim sudionicima u korporaciji, kao što su nadzorni odbor, menadžeri, dioničari i drugi dionici te uređuje pravila i procedure donošenja odluka o korporativnim poslovima.

U novije vrijeme pojam vladavine prenosi se na društvo u cijelosti. Radna skupina za vladavinu Međunarodnog instituta upravnih znanosti (International Institute of Administrative Sciences) 1996. godine dala je koristan sažetak šireg koncepta vladavine:

- "Vladavina se odnosi na proces u kojem sastavnice u društvu ostvaruju moć i vlast te utječu i donose politike i odluke koje se tiču javnog života, gospodarstva i socijalnog razvoja.

- Vladavina je širi pojam od vlade, čije glavne sastavnice uključuju ustav, zakonodavstvo, izvršnu i sudsku vlast. Vladavina uključuje interakciju između tih formalnih institucija i institucija civilnog društva.

- Vladavina nema automatski normativno određenje. Ipak, tipični kriterij za procjenu vladavine u posebnom kontekstu može uključiti stupanj legitimiteta, predstavljenosti, polaganja računa (accountability) i učinkovitosti kojom su vođeni javni poslovi.

- Vladavina je različita od menadžmenta (rukovođenja), koji je ponajprije funkcija osoblja, premda se u manjim i srednjim organizacijama obje funkcije preklapaju. Korisno je misliti o nadzornom odboru kao žarištu vladavine, a izvršni su direktori žarišna točka menadžmenta." 10

Vladavina modernom korporacijom široko se shvaća kao mehanizmi, odnosi i procesi za balansiranje interesa dionika. Ona podrazumijeva pravila i procedure za donošenje odluka, polaganje računa, transparentnost te distribucijska prava. Struktura korporativne vladavine propisuje raspodjelu prava i odgovornosti

8 Opširnije u: van Berkel, R.; de Graaf, W.; Sirovátka, T. (ur.), The Governance of Active Welfare States in Europe, Palgrave Macmillan, Basingstoke, 2011.

9 Vidi više: Levi-Faur, D., From "Big Government" to "Big Governance"?, u: Levi-Faur, D. (ur.), The Oxford Handbook of Governance, Oxford University Press, Oxford, 2012., str. $3-18$.

10 Anheier, K. H., Nonprofit Organizations. Theory, Management, Policy, Routledge, London i New York, 2014., str. 413. 
među dionicima, uključujući vlasnike, dioničare, dužnike, odbore, menadžere, zaposlenike, kupce i regulatore. Korporativna vladavina osigurava okvir u kojem se postavljaju korporativni ciljevi, načini za njihovo postizanje, monitoring uspješnosti te koje uloge različiti akteri igraju u tim aspektima. ${ }^{11}$

Kodeksi korporativne vladavine redovito se pozivaju na načela koja je OECD objavio 2004. godine, a poslije su dopunjavana i evoluirala su. ${ }^{12}$ Skandali u velikim korporacijama početkom dvijetisućitih i posebno u globalnoj financijskoj krizi 2008. na dnevni red rasprava stavili su pitanja promašenijih korporativnih vladavina. ${ }^{13}$ Različiti korporativni oblici (privatni, javni, neprofitni, hibridni) potrebuju različite režime vladavine.

Vladavina kao važan koncept $\mathrm{u}$ društvenim znanostima ima imidž i značenje promjene. Njezino se značenje odnosi na: strukture - formalne i neformalne institucije; procese - dinamiku i upravne funkcije uključene u procese izrade politike; mehanizme - institucijske procedure odlučivanja i strategije - oblikovanje institucija i mehanizama kako bi se izoštrili izbori i preferencije. ${ }^{14}$

Prema Rhodesu ${ }^{15}$ vladavina (governance) nije sinonim za vladu (government) i odnosi se na novi proces vladanja (governing); ili promjenu uvjeta uređenog pravila; ili nove metode kojima se vlada društvom. Rhodes vladavinu definira kao minimalnu državu, društveno-kibernetički sustav i kao samoorganizirajuće mreže čija su obilježja: (1) međuovisnost organizacija, obuhvaćaju se i nedržavni akteri - mijenjaju se međe države, kao i međe između javnog, privatnog i civilnog sektora, (2) stalna je interakcija između članova mreže zbog potrebe razmjene resursa i pregovaranja o zajedničkim ciljevima, (3) interakcija je poput igre, ukorijenjene u povjerenju i regulirane pravilima o kojima pregovaraju i usvajaju

11 Opširnije u: Anheier, K. H.; Abels, M. C., Corporate Governance in Comparative Perspectives, u: Anheier, K. H.; Baums, T. (ur.), Advances in Corporate Governance: Comparative Perspectives, Oxford University Press, Oxford, 2020., str. 1 - 9.

12 OECD Principles of Corporate Governance, https://www.oecd.org/corporate/ca/ corporategovernanceprinciples/31557724.pdf (15. studenoga 2021.). U ovom dokumentu nalazi se i naslov na francuskom jeziku: Principes de gouvernement d'entreprise de l'OCDE. Zanimljivo, u njemačkom jeziku koristi se pojam corporate governance, vidi: Hopt, J. K., Corporate Governance von Finanzinstituten: Empirische Befunde, Theorie und Fragen in den Rechts- und Wirtschaftswissenschaften, Zeitschrift für Unternehmens- und Gesellschaftsrecht, vol. 46, br. 4, 2017., str. 438 - 459.

13 Anheier, K. H.; Abels, M. C., Corporate Governance: What are the Issues?, u: Anheier, K. H.; Baums, T. (ur.), Advances in Corporate Governance: Comparative Perspectives, Oxford University Press, Oxford, 2020., str. $10-42$.

15 Rhodes, R. A. W., The New Governance: Governing Without Government, Political Studies, vol. 44, br. 4, 1996., str. $652-667$. 
ih sudionici mreža, (4) značajan stupanj autonomije u odnosu na državu, mreže ne polažu račun državi i one su samoorganizirajuće. Premda država nema povlaštenu poziciju, ona mrežama može upravljati indirektno i nesavršeno. Rhodes

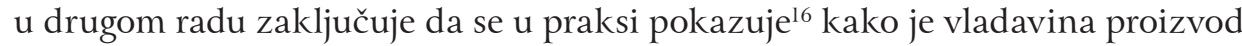
uvjetovan različitim akcijama i političkim borbama, oblikovan vjerovanjima agenata ukorijenjenih u različite tradicije.

Važno je istaknuti kako vladavina, primjerice, u procesima razvoja urbanih područja uvijek uključuje tijela vlasti na različitim razinama, ali to ne znači da je vlada stranka koja rukovodi (manages) ili upravlja (administers) vladavinom (governance) ${ }^{17}$

Tematiziranje paradigme nove javne vladavine (new public governance) Osbor$n \mathrm{e}^{18}$ stavlja u kontekst ranijih paradigmi, a posebno ističe ključne elemente novog javnog menadžmenta kao tranzicijske faze: pozornost na lekcijama iz rukovođenja u privatnom sektoru, usmjerenost na poduzetničko vodstvo u organizacijama javnih usluga te povećana uloga tržišta u resursima i uslugama javnog sektora. Naspram paradigmi javnog upravljanja (public administration) koja dominira poslije Drugog svjetskog rata i novog javnog menadžmenta koji se javlja krajem 70-ih godina 20. stoljeća, paradigma nove javne vladavine polazi od pluralne države, u kojoj više međuovisnih sudionika doprinosi isporuci javnih usluga te pluralističke države, u kojoj višestruki procesi informiraju sustav izrade politika. Kao posljedica tih dvaju oblika pluralnosti fokus nove javne vladavine u velikoj mjeri je usmjeren na međuorganizacijske odnose, obilježene povjerenjem, i procese vladavine te naglašava učinkovitost i ishode usluga. H. Anheier u tom smislu zaključuje kako su škole javne politike (schools of public policy) evoluirale iz škola javne uprave (schools of public administration) (kako rukovoditi javnim sektorom u nastajanju) u škole javne politike (kako oblikovati i provoditi dane politike), a sada u škole vladavine (schools of governance) (kako riješiti i rukovoditi javnim problemima). ${ }^{19}$

Novi javni menadžment građane tretira kao potrošače i klijente, dok se u novoj javnoj vladavini država prema građanima i skupinama građana odnosi kao

16 Opširnije u: Rhodes, R. A. W., Waves of Governance, u: Levi- Faur, D. (ur.), The Oxford Handbook of Governance, Oxford University Press, Oxford, 2012., str. 33 - 48.

17 Franzen, A.; Hobma, F.; de Jonge, H.; Wigmans, G. (ur.), Management of Urban Development Processes in the Netherlands - Governance, Design, Feasibility, Techne Press, Amsterdam, 2011., str. 10.

18 Osborne, op. cit. u bilj. 6.

19 Anheier, K. H., On the Future of the Public Policy School, Global Policy, vol. 10, br. 1, 2018., str. 81. 
prema suproizvođačima i sukreatorima, koji su uključeni u više horizontalne suradničke odnose. ${ }^{20}$

Vukojičić-Tomić zaključuje kako se koncept dobre vladavine razvija kao odgovor na loše reforme javnih uprava provedene u okviru koncepta novog javnog menadžmenta (new public management). ${ }^{21}$ Dobra vladavina značajan je odmak od tradicionalne uloge državne uprave po načelu “zapovijedaj i kontroliraj”.

Dobra vladavina prema Anheieru ${ }^{22}$ znači učinkovit, djelotvoran i pouzdan skup legitimnih institucija i aktera uključenih u proces koji se bavi pitanjima javnog značenja, bez obzira na to je li riječ o financijskom tržištu, zdravstvenoj skrbi ili migracijama na lokalnoj, nacionalnoj ili međunarodnoj razini. Međuovisnost institucija i događaja u suvremenom svijetu podrazumijeva ograničenja i prilike. Kao primjer međuovisnosti i razvoja prakse dobre vladavine Anheier ${ }^{23}$ navodi primjer rijeke Rajne koja je sredinom prošlog stoljeća bila ekstremno onečišćena, a često je poplavama uzrokovala velike štete. Zatim su susjedne zemlje, ministarstva, regionalne i lokalne vlasti, tvornice, rudarske i brodarske kompanije te organizacije civilnog društva poduzele zajedničku akciju. Aktivnosti $\mathrm{u}$ tom projektu provode se na temelju usuglašenog policy dokumenta, a njegovu provedbu prati međunarodno povjerenstvo. Pretvaranje Rajne zajedničkim djelovanjem iz ekološki mrtvog brodarskog kanala u rijeku s prepoznatljivom kvalitetom vode predstavlja uspješan primjer dobre vladavine.

Rentzsch istražuje primjer dobre vladavine s inovativnim učincima, projekt Optionskommune iz Münstera u Njemačkoj, koji je nezaposlenosti pristupio kao strukturnom, a ne individualnom problemu. ${ }^{24} \mathrm{U}$ okviru projekta umreženi su relevantni dionici od lokalne vlasti do poslovnog sektora, a ključna osnovica koncepta vladavine bila je tijesna suradnja ureda za zapošljavanje i ureda za socijalnu skrb te civilnih organizacija koje pružaju socijalne usluge kao ulog u novu politiku zapošljavanja. Zajednički rad na politici tržišta rada bio je usmjeren na različite ciljne skupine, što prije nije bio slučaj, a dodana vrijednost je i

20 Opširnije u: Pestoff, V.; Brandsen, T.; Verschuere, B. (ur.), New Public Governance, the Third Sector and Co-Production, Routledge, New York i London, 2012.

21 Vukojičić Tomić, T., Dobra vladavina: od konceptualizacije do realizacije, Politička misao, vol. 53, br. 2, 2016., str. 105 - 130.

22 Anheier, K. H., Governance: What Are the Issues?, u: Hertie School of Governance, The Governance Report 2013, Oxford University Press, Oxford, 2013., str. 13.

23 Anheier, op. cit. u bilj. 22, str. 15.

24 Više vidi: Rentzsch, C., Everybody on Board? Opportunity Structures for Social Innovations in Münster, u: Brandsen, T.; Cattacin, S.; Evers, A.; Zimmer, A. (ur.), Social Innovations in the Urban Context, Springer, Cham, Heidelberg, New York, Dordrecht i London, 2016., str. $45-64$. 
veća usmjerenost na prevenciju nezaposlenosti. Analizirani učinci ovog projekta kvalificiraju ga kao "ulaganje u budućnost". ${ }^{25}$

Izgradnja kapaciteta modernih država u odgovorima na rastuće izazove vidi se u novom tipu vladavine s naglašenom ulogom inovacija. ${ }^{26}$ Ističe se važnost pripravnosti vladavine (governance readiness), što podrazumijeva pripremljenost i sposobnost za rješavanje problema. Međuovisnost i koordinacija između države i nedržavnih aktera računa s raspoloživošću alata kojima se naslovljavaju policy problemi na održiv način. Pripravnost vladavine zahtijeva pažljivu raspravu o tome kako se prilagoditi suvremenim izazovima utemeljenim na pojmovima predviđanja i pruživosti (resilient). ${ }^{27}$ Određene probleme i njihove učinke može se predvidjeti. S druge strane, pruživost zahtijeva od aktera da imaju dovoljno resursa kako bi se bili u stanju vratiti u prvotno stanje kada potencijalni rizik postane realnost. U tom kontekstu daje se veći broj preporuka kako bi se povećali kapaciteti i doprinosi javne uprave za bolju vladavinu. ${ }^{28}$

Bozzini i Enjolras analizirajući paradigmu vladavine posebno ističu ulogu posredničkih organizacija, a u slučaju organizacija civilnog društva one su bliže problemima i s njima izgrađeni partnerski odnosi mogu dati odgovore na rastuće izazove potrebnih policy promjena u socijalnoj politici. U takvom konceptu dolazi se do zajedničkih rješenja za kompleksne socijalne probleme, a vlade u tom poslu ne djeluju same te se uključuju u suradničko upravljanje, suupravljanje i koregulaciju pri čemu se prelazi granica između javne i privatne sfere. ${ }^{29}$

Općenito, prema Sirovatki i Winkleru, napori za inoviranjem programa socijalne politike, kako bi aktivni programi više doprinosili učinkovitijoj socijalnoj državi, ovise o novim tipovima vladavine koji podrazumijevaju bolju suradnju

25 Niz relevantnih praksi urbane vladavine mogu se naći u: Brandsen, T.; Cattacin, S.; Evers, A.; Zimmer, A. (ur.), Social Innovations in the Urban Context, Springer, Cham, Heidelberg, New York, Dordrecht i London, 2016.

26 Opsežnije u: Lodge, M.; Wegrich, K., Setting the Scene: Challenges to the State, Governance Readiness, and Administrative Capacities, u: Hertie School of Governance, The Governance Report 2014, Oxford University Press, Oxford, 2014., str. 15 - 26.

27 Izazovi prevođenja pojma resilient bit će obrađeni u drugom dijelu teksta.

28 Više vidi: Lodge, M.; Wegrich, K., Enhancing Administrative Capacities for Better Governance: Seven Recommendations, u: Hertie School of Governance, The Governance Report 2014, Oxford University Press, Oxford, 2014., str. 151 - 170.

29 Bozzini, E.; Enjolras, B. (ur.), Governing Ambiguities: New Forms of Local Governance and Civil Society, Nomos, Baden-Baden, 2012. Ova opsežna studija može dati poticaje za empirijska istraživanja glede razvoja lokalne vladavine. 
dionika, kao i njihove odgovarajuće menedžerske i provedbene kapacitete. ${ }^{30}$ Tema odnosa između civilnog sektora i vlasti posljednjih je godina aktualizirana zbog velikog porasta broja radova o promjenama paradigmi vezanih uz vladavinu i novih oblika vladavine u socijalnoj politici. Uobičajeno se govori o promjeni, tj. pomaku od vlade (government) prema vladavini (governance). Dakle, kod pojma vladavina riječ je o izvedenici koja je etimološki jasna i stručnjacima razumljiva. Vladajući (governing) pristupom odozgo, izdavanjem naloga i kontroliranjem, odnosno upravljanjem, vlade se ne mogu učinkovito i djelotvorno nositi s problemima i razvojnim izazovima s kojima su suvremena društva suočena. Kako bi odgovorile na takve izazove, vlade prihvaćaju vladanje odozdo, po horizontalnom načelu suradnje s ostalim dionicima, pa su onda u prilici mobilizirati sve raspoložive resurse, izgraditi povjerenje i novu mrežu suradnje te razviti koncept vladavine (governance). Dobra vladavina, prema Staingu i Kayseru, podrazumijeva raznolikost dionika, uključujući civilne organizacije, u procesima javnih politika s ciljem ispunjenja zajedničkih i općih interesa. ${ }^{31}$ Civilne organizacije imaju sve značajnije mjesto i ulogu unutar takvih novih aranžmana koji istodobno donose i izazove promjenjivog okruženja u kojem djeluju.

Sørensen i Torfing razlikuju prvu i drugu generaciju istraživanja o mrežama vladavine. ${ }^{32}$ Prva generacija istraživanja vladavine bila je uglavnom zaokupljena prepoznavanjem događanja nečeg novog te konceptualizacijom mreže vladavine različitom od države i tržišta. Naglasak je bio na činjenici kako su politike rezultat procesa vladanja koji nije kompletno kontroliran od javnih vlasti, nego uključuje "pluricentrične" mreže. Druga generacija istraživanja usmjerena je

30 Sirovatka i Winkler, kao dio komparativnog istraživačkog projekta, upućuju na probleme provedbe mjera aktivacije na tržištu rada u Češkoj, a u okviru programa Europskog socijalnog fonda koji se proceduralno oslanja na načela vladavine. Za razliku od drugih razvijenih država EU-a obuhvaćenih ovim istraživanjem Češka je ovisna o prijeđenom putu (path dependency), u izradi mjera nedostaje koordinacija među razinama vlasti i dionicima, a javljaju se neformalne potporne mreže koje ispunjavaju praznine u konceptu vladavine. Više vidi: Sirovatka, T.; Winkler, J., Governance of Activation Policies in the Czech Republic: Uncoordinated Transformation, u: van Berkel, R.; de Graaf, W.; Sirovátka, T. (ur.), The Governance of Active Welfare States in Europe, Palgrave Macmillan, Basingstoke, 2011., str. 173 - 194.

31 Staing, P.; Kayser, A. M., Governance Indicators: Some Proposals, u: Anheier, K. H. (ur.), Governance Challenges and Innovations - Financial and Fiscal Governance, Oxford University Press, Oxford, 2013., str. 189 - 220.

32 Sørensen, E.; Torfing, J., Introduction. Governance Network Research: Towards a Second Generation, u: Sørensen, E.; Torfing, J. (ur.), Theories of Democratic Network Governance, Palgrave Macmillan, Basingstoke, 2007., str. $1-21$. 
širim istraživanjima i više je zaokupljena funkcioniranjem mreža i njihovim implikacijama za policy proces.

U okviru opsežnih istraživanja Hertie School of Governance ${ }^{33}$ polazi se od kritike postojećih mjerenja koncepta vladavine ističući kako njihovi indikatori više mjere vladu, a manje vladavinu. ${ }^{34}$ Predloženi su novi indikatori koji ispunjavaju tri kriterija: treba uzeti temeljni pojam vladavine kao višerazinski i višeakterski sustav; treba nasloviti neovisnost; treba imati analitički i policy orijentirani fokus te biti više nego opisan. Taj pristup indikatore stavlja u tri kontrolne ploče vladavine (governance dashboard): transnacionalnu, nacionalnu i gradsku.

Prema istraživanjima Anheiera, Kaufmanna i Ziaja ${ }^{35}$ globalna financijska i gospodarska kriza 2008. godine dugoročno je dovela u pitanje institucionalne kapacitete nacionalnih i međunarodnih organizacija glede oblikovanja i provedbe koncepta vladavine. Posebno se ističu problemi rubnih zemalja EU-a i pada povjerenja građana u njihove institucije. Izgradnja povjerenja među mlađom populacijom i ranjivim skupinama, posebno onima s nižim prihodima, vidi se kao ključni ulog u jačanje dobre vladavine.

\section{KONTEKST PROMICANJA KONCEPTA VLADAVINE U EU-u}

Koncept vladavine u politici Europske unije treba osnažiti konvergencijske procese te doprinijeti učinkovitosti i djelotvornosti kohezijske politike. Prihvaćanje i provedba paradigme vladavine u pripremi, donošenju odluka i u provedbi bio je izazov za nove članice. $U$ ovom području Unija podupire i brojne istraživačke projekte koji imaju obilježja akcijskih istraživanja te uključuju i neakademske dionike.

Tijekom 90-ih godina 20. stoljeća socijalna partnerstva vlada, poslodavaca i sindikata u državama članicama bila su okvir socioekonomske vladavine, a njih su osnivale i članice koje nisu imale korporativističku tradiciju. Prema Rho-

33 Hertie School od 2013. objavljuje godišnjak The Governance Report naslovljavajući relevantne teme i povezujući ih s različitim događajima i rezultatima istraživanja. Time se na razmatranje izrađivačima politika i analitičarima daju nove ideje, znanja i alati za provedbu politika i programa koji vode boljim rješenjima javnih problema. Osobito se propituju kapaciteti suvremenih država za rješavanje problema. Više vidi na: https://www.hertie-school.org/en/governancereport (15. travnja 2021.). Staing; Kayser, op. cit. u bilj. 31.

35 Opsežnije u: Anheier, K. H.; Kaufmann, S.; Ziaja, S., Ten Years After: The Global Financial and Economic Crisis - Impact and Implications, u: Hertie School of Governance, The Governance Report 2018, Oxford University Press, Oxford, 2018., str. 13 - 28. 
desu ${ }^{36}$ to su bili okviri kroz koji su postignuti ciljevi promjene plaća, fiskalne konsolidacije i reformi socijalne države te općenito okviri izrade novih politika. Takvim su nastojanjima poticani konvergencijski procesi u Uniji.

Metoda otvorene koordinacije i koncept dobre vladavine bili su alati kojima su jačani procesi konvergencije u dvijetisućitima. Opsežna istraživanja koja je Unija u tom vremenu financirala trebala su pomoći u širenju tih praksi u novim članicama. ${ }^{37}$ Kohler-Kocha i Eising su širenje koncepta vladavine na nove članice držali kao doprinos procesu njihove europeizacije. ${ }^{38}$

Metoda otvorene koordinacije, prihvaćena u okviru Lisabonske strategije, još je od prije prokušan način poticanja suradnje, razmjene najboljih praksi i dogovora o zajedničkim ciljevima i smjernicama država članica. ${ }^{39}$ Ona se od 1997. godine počela primjenjivati u području politike zapošljavanja, da bi se zatim postupno proširila i na područja borbe protiv siromaštva i socijalne isključenosti, mirovina i dugotrajne skrbi. Na razini EU-a definiraju se zajednički ciljevi (npr. smanjivanje stopa nezaposlenosti ili siromaštva), a zemlje članice odgovorne su za provedbu takvih ciljeva. Međutim, metoda otvorene koordinacije predviđa i definiranje zajedničkih kriterija kojima će se mjeriti uspjeh država članica (u području borbe protiv siromaštva i socijalne isključenosti to su tzv. leakenski indikatori kojima se precizno mjere različiti aspekti siromaštva i socijalne isključenosti), uspoređivati njihove prakse te utvrđivati prijedlozi za promjene. Metoda otvorene koordinacije predviđa i sudjelovanje širokog kruga dionika $\mathrm{u}$ definiranju i provođenju pojedinih politika. Prema istraživanju Bežovana

36 Vidi: Rhodes, M., The Role of Social Pacts in European Socio-economic Governance, Policy Brief 34, 2008., http://www.eunewgov.org/database/PUBLIC/Policy_Briefs/NEWGOV_Policy_Brief_no34.pdf (15. prosinca 2020.).

37 Prethodno spomenuta istraživanja "Efficient and Democratic Governance in a Multi-level Europe" - CONNEX i "New Modes of Governance" - NEWGOV bila su dijelom akcijski orijentirana, a partneri su bili i drugi dionici, osobito organizacije civilnog društva, koji su sudjelovali u radnim skupovima. Jedan od praktičnih ishoda projekta NEWGOV, u to vrijeme veoma koristan, bio je i pojmovnik u kojem se objašnjavaju i pojmovi governance te mode of governance, vidi: http://www.eu-newgov. org/public/Glossary.asp (15. prosinca 2020.).

38 Kohler-Koch, B.; Eising, R. (ur.), The Transformation of Governance in the European Union, Routledge, London i New York, 2005.

39 Više vidi: Zeitlin, J.; Pochet, P.; Magnusson, L. (ur.), The Open Method of Coordination in Action: The European Employment and Social Inclusion Strategies, P.I.E. - Peter Lang, Bruxelles, 2005. 
i Zrinščaka to je doprinos dobroj vladavini koji podrazumijeva monitoring i evaluaciju programa te njihovo inoviranje. ${ }^{40}$

Europska vladavina - bijela knjiga (European Governance. A White Paper $)^{41}$ bio je jedan od ključnih dokumenta kojima se promiče načelo dobre vladavine u Europskoj uniji. ${ }^{42}$ Taj dokument više otvara proces izrade javnih politika građanima i drugim dionicima te se zagovara uključivanje svih dionika i veća otvorenost u policy procesima. Time se doprinosi poboljšanju kvalitete javnih politika, njihovoj usklađenosti te dugotrajnosti ciljeva. Pet je načela koja podrazumijevaju kvalitetnu vladavinu: otvorenost, sudjelovanje, polaganje računa (accountability) ${ }^{43}$, učinkovitost i usklađenost. Primjena ovih načela doprinosi jačanju povjerenja te učvršćivanju temelja proporcionalnosti i supsidijarnosti.

Polazi se od pretpostavke da će Europa biti jaka, njezine institucije legitimne, politike učinkovite, a da će se građani osjećati uključenima ako način vladavine jamči suradnju između različitih razina vlasti kako bi se ispunila politička agenda Europske unije i suočilo s globalnim izazovima. U tom kontekstu 2014. godine usvojena je Povelja za višerazinsku vladavinu. ${ }^{44}$ Povelja zagovara višerazinsku vladavinu u Europi utemeljenu na koordiniranom djelovanju Europske unije, država članica, regionalnih i lokalnih vlasti prema načelima supsidijarnosti, proporcionalnosti i partnerstva, a ima oblik operativne i institucionalne suradnje u izradi i provedbi politika Europske unije.

Cilj ovog dokumenta koji je izradio Odbor za regije Europske unije jest povezati regije i gradove diljem Europe promovirajući višeakterstvo s društvenim čimbenicima kao što su socijalni partneri, sveučilišta i predstavnici civilnoga društva. Višerazinska vladavina jača otvorenost, sudjelovanje, koordinaciju i zajedničku obvezanost na isporuku ciljanih rješenja. Višerazinska vladavina pomaže da jedni od drugih uče, da se eksperimentira s inovativnim policy rješenjima, da se dijele najbolje prakse te da se dalje razvija participativna demokracija, približavajući Europsku uniju građanima.

40 Bežovan, G.; Zrinščak, S., Civilno društvo u Hrvatskoj, Naklada Jesenski i Turk i Hrvatsko sociološko društvo, Zagreb, 2007.

41 Hrvatski prijevod dokumenta objavljen je u Reviji za socijalnu politiku, vol. 12, br. 2, 2005., str. $189-213$.

42 Opsežnije u: Bežovan, G., Civilno društvo, Nakladni zavod Globus, Zagreb, 2004.

43 Accountability je prevođen kao odgovornost, što ne označava bit značenja pojma.

44 Hrvatski prijevod, Povelja o višestupanjskom upravljanju u Europi (Charter for Multilevel Governance in Europe) objavljen je u: Koprić, I.; Škarica, M.; Milošević, B. (ur.), Suradnja i razvoj u lokalnoj i regionalnoj samoupravi, Institut za javnu upravu, Zagreb, 2014. str. $324-326$. 
Prema Lebrunu dobar okvir za provedbu programa po načelima višerazinske vladavine daje kohezijska politika koja osigurava sredstva regionalnim i lokalnim vlastima za poticanje gospodarskog rasta, otvaranje radnih mjesta i zatvaranje praznina u teritorijalnom razvoju u području unutarnjeg tržišta. ${ }^{45}$ Ako se lokalne vlasti dobro koriste strukturnim fondovima za promicanje ulaganja u partnerstvu s javnim i privatnim sektorom, može se dogoditi ekonomski oporavak.

Važan doprinos jačanju koncepta vladavine, kao važnog instrumenta konvergencije, daju i istraživački projekti koje financira EU. ${ }^{46}$ Njihov je opći cilj razviti prilagođene strukture vladavine na različitim razinama.

U razvojnoj perspektivi EU-a 2021. - 2027. koncept dobre vladavine znatnim se dijelom oslanja na povećanu participaciju građana. ${ }^{47}$ Primjerice, $u$ okviru politike urbanog razvoja, koja zapravo u Hrvatskoj ranije nije postojala, održiva urbana vladavina temelji se, prema van Heerden, na trima komponentama: višerazinska vladavina, koja se odnosi na koordinaciju i poravnanje aktera između različitih razina vlasti; višedionički pristup, koji se odnosi na uključivanje svih relevantnih aktera u cijeli policy ciklus; pristup odozdo i participativni pristup, koji se odnosi na korištenje inicijativa pod vodstvom zajednice kako bi se ohrabrilo uključenost i odgovor lokalnih aktera. ${ }^{48}$ Očekivano, u projektima vodeću ulogu najčešće imaju predstavnici izabranih tijela vlasti, međutim, to ne znači njihovu dominaciju nad drugim dionicima. ${ }^{49}$

45 Vidi više: Lebrun, M., Multilevel governance as way towards a more involved and accountable political union, European View, vol. 13, 2014., str. 327 - 332.

46 U okviru Horizon 2020 - Work Programme 2018-2020, Europe in a changing world - Inclusive, innovative and reflective societies poziva Vladavina za budućnost otvoren je natječaj za 23 tematska područja. Vidi: https:/ec.europa.eu/research/participants/ data/ref/h2020/wp/2018-2020/main/h2020-wpl820-societies_en.pdf (18. studenoga 2020.).

47 Vidi: High-level conference "Engaging citizens for good governance in Cohesion Policy”, veljača 2020., https://ec.europa.eu/regional_policy/en/conferences/citizens_ good_governance (10. listopada 2020.).

48 Opširnije u: van Heerden, S., Governance, u: Fioretti, C.; Pertoldi, M.; Busti, M.; van Heerden, S. (ur.), Handbook of Sustainable Urban Development Strategies, Publications Office of the European Union, Luxembourg, 2000., str. 90 - 125.

49 Projekti EU-a, kao primjeri dobre prakse, ističu izazove razvoja urbane vladavine, a ostvareni rezultati utemeljeni su na promjeni načina mišljenja (mindset), dijeljenju ideja i povjerenju dionika. Sljedeći je izazov prenošenje vodstva iz gradske vijećnice u opću javnost. Vidi: Guardo, J., A Multi Sectoral Approach to Funding and Finance, webinar "FUNDING. Multiple Funding Sources as the Key for Integration and Sustainability”, UDN webinar series 'Six Building Blocks to Sustainable Urban Development' based on the Handbook of Sustainable Urban Development Strategies, 
Dobra vladavina treba doprinijeti održivom urbanom razvoju, a u Hrvatskoj se povećava broj urbanih područja koja će se koristiti tim mehanizmom sa sedam na četrnaest, s tim da se za te programe povećavaju sredstva EU-a. ${ }^{50}$ Prema Ivanu Tosicsu, mehanizam integriranih teritorijalnih ulaganja, kao holistički i inovativan pristup, računa s okvirom prakticiranja načela dobre vladavine i proizvodnjom sinergijskih učinaka. ${ }^{51} \mathrm{U}$ pripremi strategija za novu perspektivu bilo bi korisno da je barem provedeno istraživanje o ulozi partnerskih vijeća koja su zamišljena kao žarišta vladavine. ${ }^{52}$

\section{TEMA VLADAVINE U HRVATSKOJ}

Kao što je rečeno, pojam governance u Hrvatskoj se različito prevodi, glede prijevoda iznose se dvojbe, pa se u tom smislu može dvojiti o njegovu značenju. Ovdje se analiziraju radovi domaćih autora koji se bave konceptom governance s usmjerenošću na značenje pojma i njegov prijevod. Analiziraju se i važni razvojni dokumenti te se naglašavaju različiti prijevodi tog pojma u visokoškolskoj nastavi.

https://udn-handbook.tw.events/, (25. studenoga 2020.). Dakle, ova je inovacija vladavine vezana uz grad Bilbao, a ranije je urodila globalno poznatim Bilbao efektom.

50 Vidi: https://razvoj.gov.hr/vijesti/grad-vinkovci-dobio-priliku-za-koristenje-eu-sredstava-putem-itu-mehanizma/4015 (10. studenoga 2020.).

51 Tosics, I., Integrated territorial investment - A missed opportunity?, u: Bachtler, J.; Berkowitz, P.; Hardy, S.; Muravska, T. (ur.), EU cohesion policy: reassessing performance and direction, Routledge, London, 2017., str. 284 - 296. Tosics je jedan od najrelevantnijih istraživača za temu integriranih teritorijalnih ulaganja, a i za teme urbanog razvoja u tranzicijskim zemljama.

52 Članovi partnerskih vijeća predstavnici su svih relevantnih lokalnih dionika. S druge strane, primjerice, kao temelje za poželjnu akademsku vladavinu bilo bi korisno istražiti sastav i ulogu savjeta sveučilišta u Hrvatskoj, kao i Nacionalnog vijeća za znanost, visoko obrazovanje i tehnološki razvoj te njegovih područnih znanstvenih vijeća. Proces izrade Nacionalne razvojne strategije do 2030. i ponuđeni strateški ciljevi razvoja u javnim su raspravama osporavani, a dokument je i tema e-savjetovanja, https://esavjetovanja.gov.hr/ECon/MainScreen?entityId=15312, (30. studenoga 2020.). Izazovna istraživačka tema bila bi analiza procesa izrade ovog krovnog razvojnog dokumenta u odnosu na standarde dobre vladavine. 
Tema vladavine u hrvatskoj javnosti došla je na dnevni red u procesu pridruživanja Europskoj uniji. ${ }^{53}$ Bađun propituje kvalitetu governancea ${ }^{54}$ i izglede njegova poboljšanja, dakle provedbe reformi u razdoblju pristupanja EU-u. Zaključuje kako je governance znatna prepreka pridruživanju zemlje EU-u. Pozitivno je to što se u posljednjim godinama ti pokazatelji polako popravljaju, a jedini je "sumnjivi" element djelotvornost države. Praćena su i ocjenjivana načela dobre vladavine u izvještajima Europske komisije o napretku Republike Hrvatske..$^{55}$ Jačanje upravnih kapaciteta te šire uključivanje građana i organizacija civilnog društva uz poštovanje demokratskih procedura bili su prepoznati izazovi glede ostvarivanja načela dobre vladavine.

U tekstu I. Perko-Šeparović, koji ima nakanu biti praktičan i čije bi ideje trebale biti primjenjive, pojam governance prevodi se kao upravljanje i navodi se: "Dobro upravljanje sposobnost je formalne i neformalne institucionalne okoline (u kojoj pojedinci, društvene skupine, građanske organizacije i donositelji politika djeluju jedni na druge) kako bi provodili javne politike i poboljšali koordinaciju privatnog sektora. "Governance" struktura igra kritičnu ulogu u formuliranju i provođenju gospodarskih i socijalnih politika, razvojnih projekata te razvoja i koordinacije privatnog sektora. U odnosu na probleme poticanja, provođenja i održavanja vladinih politika, političke institucije u "governance" strukturi pojedine zemlje imaju dominantnu ulogu jer određuju način na koji su različiti akteri uključeni u

53 U Hrvatskoj se pojam vladavina kolokvijalno upotrebljava kako bi se obilježilo razdoblje vladanja nekih povijesnih vladara. K tome, pojam Rule of law preveden je kao vladavina prava. Time se upućuje na moguće pluralno značenje i razumijevanje pojma vladavine.

54 Više vidi: Bađun, M., Governance i javna uprava u kontekstu pridruživanja Hrvatske Europskoj uniji, u: Ott, K. (ur.), Pridruživanje Hrvatske Europskoj uniji: Izazovi institucionalnih prilagodbi, Institut za javne financije i Zaklada Friedrich Ebert, Zagreb, 2004., str. $125-157$.

Autorica upotrebljava pojam governance te dvoji o pojmu kojim bi se preveo na hrvatski jezik, ne slažući se s prevođenjem tog pojma kao upravljanje. Bolji joj se čini pojam vladanje u kombinaciji s javnim upravljanjem. I u drugim zemljama u regiji ne postoji suglasje o prevođenju pojma governance. U Sloveniji (informacije Frane Adama) upotrebljava se pojam vladavina, ali i upravljanje, u Češkoj (informacije Martina Potučeka i Tomaša Sirovatke) postoji podijeljenost akademske zajednice, dio njih koristi pojam vládnutí, a u službenim dokumentima pojam se prevodi kao upravljanje. U Poljskoj (informacija Anne Domaradzka-Widła) rządzenie, rząd je vlada. U Mađarskoj (informacija Ivana Tosicsa) u upotrebi je pojam kormányzás - vladavina. U Francuskoj (informacija Adriana Diaconua) gouvernance, a u Španjolskoj gobernanza (informacija Rafael Chaves Avila). U Njemačkoj (informacija Annette Zimmer), zanimljivo, preuzet je engleski governance.

55 Vidi: Vukojičić Tomić, op. cit. u bilj. 21. 
političke procese; koje su vrste gospodarskih reformi moguće i kako je oblikovano ponašanje pojedinih sudionika." ${ }^{56}$ Međutim, navođenje ovog pojma i u "governance" inačici može upućivati i na autoričine dvojbe glede prevođenja pojma.

Na različita značenja governance za različite autore te na teškoće njegova jednoznačnog i nedvosmislenog tumačenja te otežanog prijevoda na hrvatski jezik upozorava i V. Đulabić. ${ }^{57}$ Citira se više autora i značenja ovog pojma te se, među ostalim, on odnosi na "... ukupnost vladavinskih institucija u određenoj političkoj zajednici, a ponekad na upravljanje javnim sektorom koje je vođeno određenim vrijednostima." Međunarodne organizacije (Svjetska banka, UN, OECD) u tom kontekstu govore o modernizaciji javne uprave u pojedinim zemljama, pa govore o good governance, a Đulabić to prevodi kao dobro upravljanje, dobro vladanje. ${ }^{58}$ Međutim, Đulabić u ovom radu ne govori o konceptu good governance Europske unije. To više, važan dio ove studije pokazuje osnovne ideje modela višestupanjskog sustava upravljanja javnim poslovima (multi-level governance) s analizom procesa u Europskoj uniji.

Koprić analizira dobro upravljanje (good governance) u gradovima u kontekstu decentralizacije. Dobro upravljanje posebno drži “... građane partnerima (suradnicima) koji suodređuju učinke javne uprave." ${ }^{59}$ Dakle, navodeći načela Europske vladavine - bijele knjige, bez citiranja dokumenta, zagovara se europska doktrina dobrog upravljanja.

U Strategiji reforme državne uprave za razdoblje 2008. - 2011. ${ }^{60}$ zagovara se široka participacija, pri čemu javnost, civilno društvo i građani moraju biti pitani ne samo tijekom oblikovanja, već i tijekom provedbe reformi. Koncept dobrog upravljanja (good governance) tematizira se dosta načelno, bez pozivanja na $E u$ ropsku vladavinu - bijelu knjigu.

U razdoblju pristupanja Hrvatske Europskoj uniji Koprićcl vidi uloge civilnog društva i akademske zajednice, kao važnih dionika dobrog upravljanja, istina

56 Perko-Šeparović, I., Uvod - pojam dobrog upravljanja i razvoja, u: Perko-Šeparović, I. (ur.), Priručnik za dobro upravljanje, Hrvatski pravni centar, Zagreb, 2006., str. 3.

57 Više vidi: Đulabić, V., Regionalizam i regionalna politika, Društveno veleučilište u Zagrebu, Zagreb, 2007.

58 Đulabić, op. cit. u bilj. 57, str. 31.

59 Koprić, I., Decentralizacija i dobro upravljanje gradovima, Hrvatska javna uprava, vol. 9 , br. 1, 2009., str. 72 .

60 Strategija reforme državne uprave za razdoblje 2008. - 2011., Hrvatska i komparativna javna uprava, vol. 8, br. 2, 2008., str. 315 - 342.

${ }_{61}$ Više vidi: Koprić, I., Contemporary Croatian Public Administration on the Reform Waves, Godišnjak Akademije pravnih znanosti Hrvatske, vol. 2, br. 1, 2011., str. 1 - 40. 
kao ograničene, ali koje se stalno povećavaju. Više autora ističe da je za razvoj dobrog upravljanja važno povjerenje, suradnja i socijalni kapital. ${ }^{62}$

S druge strane, Koprić63 ističe kako je široka participacija građana i formiranje lokalnih mreža okvir unutarnje decentralizacije temeljnih jedinica te je to neizostavna komponenta dobrog lokalnog upravljanja. U tom smislu za Koprića je jačanje novih oblika lokalne vladavine (governance) te unutarnje decentralizacije važnije od tradicionalnog balansa sa središnjom državom. U tom kontekstu neuspješnu europeizaciju hrvatske mjesne samouprave obilježava i činjenica nerazvijenosti dobrog lokalnog javnog upravljanja. ${ }^{64}$ Ovo istraživanje pokazuje da mjesna samouprava ima potencijal koji nije iskorišten.

Participacija građana jedan je od ključnih temelja koncepta dobre lokalne vladavine, međutim, istraživanje Vukojičić Tomić i Manojlović Toman pokazuje da su u bolje razvijenom urbanom području Hrvatske građani nezainteresirani za mjesnu samoupravu i da je teško doći do građana. ${ }^{65}$

Strategija razvoja javne uprave za razdoblje od 2015. do 2020. godine ${ }^{66}$ ističe kako je potrebno trajno jačati kompetencije svih zaposlenih u javnoj upravi i kapacitete za dobro upravljanje. Istaknuta je i posebna mjera - jačati kapacitete za dobro upravljanje. Očekuje se da će dio rukovoditelja pohađati programe za dobro upravljanje. ${ }^{67}$ Strategija se poziva na Bijelu knjiga o europskom javnom upravljanju (A White Paper on European Governance) Europske komisije iz 2001., međutim, ne upućuje se na hrvatski prijevod toga dokumenta.

62 Opširnije u: Koprić, I.; Musa, A.; Giljević, T. (ur.), Građani, javna uprava i lokalna samouprava: povjerenje, suradnja, potpora, Institut za javnu upravu, Zagreb, 2017. U ovom zborniku radova veći broj autora upotrebljava pojam upravljanje za governance, a neki se koriste i pojmom vladavina.

63 Koprić, I., Suvremeni trendovi u razvoju lokalne samouprave i hrvatska lokalna i regionalna samouprava, u: Koprić, I. (ur.), Europeizacija hrvatske lokalne samouprave: dva desetljeća primjene standarda Europske povelje o lokalnoj samoupravi, Institut za javnu upravu, Zagreb, 2018., str. 12.

64 Opširnije u: Manojlović Toman, R.; Vukojičić Tomić, T.; Koprić, I., Neuspješna europeizacija hrvatske mjesne samouprave: nedovoljna atraktivnost ili loše institucionalno oblikovanje, Godišnjak Akademije pravnih znanosti Hrvatske, vol. 10, br. 1, 2019., str. $185-210$.

65 Vukojičić Tomić, T.; Manojlović Toman, R., Role of the Sub-Municipal Government in Croatia - Learning from a Positive Experience, Review of European and Comparative Law, vol. 39, br. 4, 2019., str. 59 - 77.

66 Više vidi: Strategija razvoja javne uprave za razdoblje od 2015. do 2020. godine, Narodne novine, br. 70/2015.

67 Državna škola za javnu upravu provodi osposobljavanje za dobro upravljanje. Više na: https://www.dsju.hr/dsju/program/workshop/list (15. lipnja 2020.). 
U Sporazumu o partnerstvu između Republike Hrvatske i Europske komisije gover$n a n c e^{68}$ kao koncept modernizacije važna je tema, a preveden je kao upravljanje. Pomnjivim čitanjem teksta veoma je teško razlučiti kada je riječ o upravljanju koje je administration, a kada je riječ o upravljanju koje je governance. ${ }^{69}$ Stoga upućeni na dokument preveden na hrvatski jezik ne mogu dokučiti značenje pojma governance kao ni razviti imaginaciju o izazovima provedbe tog koncepta u politikama koje su im bliske. K tome, pojam managing authority prevodi se kao upravno tijelo. Međutim, prema njegovim zadaćama, a i značenju pojma management, riječ je o rukovodećim tijelima. Dakle, riječ je o tri pojma iz engleskog jezika koja imaju različita značenja i opisuju različite činjenice. Unatoč tome pojmovi administration, managing i governance prevode se kao upravljanje, što dovodi, zbog nepovezanosti njihova sadržaja sa sadržajima koje ti pojmovi imaju u engleskom jeziku, do njihove nerazumljivosti ili nejasnoće.

Operativni program Učinkoviti ljudski potencijali 2014. - 2020. ${ }^{70}$ temelji se na koncentraciji ulaganja u četiri tematska cilja, a jedan je od njih i dobro upravljanje. Ističe se potreba rješavanja problema uprave na središnjoj i lokalnoj razini te dodjeljivanja dostatnih sredstava EU-a za uspostavu i provedbu pravnog okvira koji podržava učinkovitu, pouzdanu i uslugama orijentiranu javnu službu. Glede

68 Sporazum o partnerstvu između Republike Hrvatske i Europske komisije za korištenje strukturnih $i$ investicijskih fondova EU-a za rast i radna mjesta u razdoblju 2014. - 2020. izvorno je pisan na engleskom jeziku. Vidi: Republic of Croatia, Partnership Agreement for the European Structural and Investment Funds in the EU Financial Period 2014-2020 - Stimulating Smart, Inclusive and Sustainable Growth, 2014., http://arhiva.strukturnifondovi. hr/UserDocsImages/prijedlogpartnerskogsporazuma.pdf (15. travnja 2021.); Petak, Z., Javne politike i problem modernog upravljanja, Hrvatska i komparativna javna uprava, vol. 8, br. 2, 2008., str. $443-462$.

69 Primjerice, poglavlje "public governance and administration" prevodi se kao "javna uprava i administracija” (op. cit. u bilj. 66, str. 35), s druge strane pojam public administration redovito se prevodi kao javna uprava, a javna uprava provodi Vladinu politiku. Javna uprava je i akademska disciplina. K tome, na mrežnoj stranici Predstavništva Europske komisije u Hrvatskoj istaknuta je publikacija Governance and public administration kojoj je preveden samo naslov, kao Upravljanje i javna uprava (https://ec.europa.eu/croatia/home_hr) (12. studenoga 2020.). Prije je napomenuto da Bađun upotrebljava izraz "governance i javna uprava". Nestandardizirani prijevod pojma governance dovodi do semantičke zbrke, nejasno je što sam pojam znači, a zatim je dvojbeno njegovo značenje u odnosu na pojmove s kojima se povezuje, ovdje s javnom upravom.

70 Operativni program Učinkoviti ljudski potencijali 2014. - 2020., http://arhiva.strukturnifondovi.hr/UserDocsImages/Documents/Strukturni\%20fondovi\%202014.\%20 \%E2\%80\%93\%202020/OPULJP\%20hr\%2020150709.pdf (15. travnja 2021.). Vidi: Petak, op. cit. u bilj. 68. 
jačanja koncepta dobre vladavine sredstva će se usmjeriti i u dva važna područja: a) za preoblikovanje poslovnih procesa u javnoj upravi i njezinu horizontalnu integraciju s fokusom na nadogradnju postojećih i osmišljavanju i provođenju novih usluga e-Vlade te b) podršku civilnom društvu. Koncept dobre vladavine trebao bi se razviti boljom suradnjom svih relevantnih dionika u pripremi, donošenju odluka (politika) i njihovoj provedbi. Gotovo svaki projekt koji se financira sredstvima EU-a trebao bi dati doprinos u razvoju dobrog upravljanja. ${ }^{71}$

Nedavno provedena evaluacija ovog Operativnog programa zaključuje: "Najviši udio 'pogrešno' identificiranih mjera i aktivnosti pripada načelu 'dobro upravljanje i suradnja s civilnim društvom', što upućuje na zaključak da prijavitelji ovo načelo nisu internalizirali do mjere da su ga bili u stanju pretočiti u smislene aktivnosti koje mu doprinose".$^{72}$ Evaluacija na ovom primjeru govori o našim znatnim deficitima glede potencijala za europeizacijom.

Strategijom regionalnog razvoja Republike Hrvatske za razdoblje do kraja 2020. godine $^{73}$ jačaju se kapaciteti dobrog upravljanja. U tom dokumentu za governance se upotrebljavaju pojmovi upravljanje, razvojno upravljanje, a zagovaraju se i načela dobrog upravljanja i višerazinskog upravljanja. ${ }^{74}$

71 U okviru obrasca za prijavu projekata EU-a računa se s pokazivanjem praktičnih znanja glede dobre vladavine, pa se u tom smislu prijavitelje pita, u poglavlju horizontalne teme: Doprinosi li projekt promicanju načela dobrog upravljanja, uključujući i suradnju s civilnim društvom? Vidi: https:/esif-wf.mrrfeu.hr/Form// (17. studenoga 2020.).

Podsjećanje na njih i njihova operacionalizacija u predloženim projektima sigurno imaju određenu težinu glede relevantnosti projekta i njegova prihvaćanja. Dakle, suradnja s organizacijama civilnog društva i drugim dionicima prevažna je za ostvarivanje postignutih ciljeva, a time se jača dobra vladavina. S druge strane, podnositelji prijedloga projekta uistinu nisu upućeni u to što taj koncept znači i koja je njegova dodana vrijednost. Vidi: http://www.esf.hr/dobro-upravljanje/ (17. studenoga 2020.).

72 Vrednovanje djelotvornosti, učinkovitosti i učinka Operativnog programa Učinkoviti ljudski potencijali 2014. - 2020., http://www.esf.hr/wordpress/wp-content/uploads/2021/07/ Zavrsno-izvjesce_evaluacija_Horizontalna_OPULJP_final_lipanj_2021.pdf, str. 23 (6. prosinca 2021.).

73 Vlada Republike Hrvatske, Strategija regionalnog razvoja Republike Hrvatske za razdoblje do kraja 2020. godine, 2017., https://razvoj.gov.hr/UserDocsImages/O\%20ministarstvu/Regionalni\%20razvoj/razvojne\%20strategije/Strategija\%20regionalnog\%20 razvoja\%20Republike\%20Hrvatske\%20za\%20razdoblje\%20do\%20kraja\%20 2020._HS.pdf (15. kolovoza 2021.).

74 U pojmovniku je upravljanje regionalnim razvojem (regional governance), a višerazinsko razvojno upravljanje i vladanje (multilevel governance). 
Udruga GONG duže se bavi temom dobre vladavine ${ }^{75}$ pod kojom podrazumijevaju: antikorupcijsku politiku, pristup informacijama, sukob interesa, medije, Sabor, Vladu, lokalne vlasti i Europsku uniju. GONG je ranije provodio i opsežna istraživanja o Indeksu dobrog upravljanja u Hrvatskoj.

Analizirajući javne politike, Z. Petak izraz public governance prevodi kao javno upravljanje, a governance kao jednostavno upravljanje. U pogledu napuštanja razumijevanja države i njezine uloge u društvu kao ključnog aktera zaključuje: "Tako shvaćeno upravljanje (governance) pojavljuje se stoga kao nov kontekst kreiranja javnih politika, koji ne uključuje samo odnos politike i javne uprave, već i čitav niz zainteresiranih aktera u horizontalnoj sferi pravljenja politika. Oni se ponašaju kao dionici u procesu - kao oni koji imaju ulog u procesu donošenja javnih odluka, u smislu da mogu imati specifične interese vezane uz neku politiku ili pak mogu biti u značajnoj mjeri pogođeni učincima te iste politike."76 Međutim, u drugom tekstu Petak dvoji o prijevodu tog pojma ističući kako je pojam governance teško jednoznačno prevesti. Napominje: "Jednostavno prevođenje tog izraza kao upravljanje jednako tako nije najbolje rješenje jer ne upućuje u potpunosti na transformaciju upravljanja što ga provode vlade, odnosno, različite razine vlasti". ${ }^{77}$

Šira hrvatska javnost o toj je temi informirana prilikom predstavljanja rezultata projekta zaklade Bertelsmann ${ }^{78}$ koji prati pokazatelje održive vladavine

75 Opširnije u: Miošić, N.; Bronić, M.; Škrabalo, M., Indeks dobrog upravljanja u Hrvatskoj 2012., GONG i Institut za javne financije, Zagreb, 2013. Prije su upotrebljavali pojam dobrog upravljanja, a onda su prešli na pojam dobra vladavina, više na: https://www.gong.hr/hr/dobra-vladavina/ (15. listopada 2020.).

76 Vidi: Petak, op. cit. u bilj. 68, str. 446.

77 Vidi: Petak, Z., Dimenzije javnih politika i javno upravljanje, Politička misao, vol. 45, br. 2, 2008., str. 12. Uglavnom ovakvo određenje donosi i rad Petek, A.; Petković, K. (ur.), Pojmovnik javnih politika, Fakultet političkih znanosti, Sveučilište u Zagrebu, Zagreb, 2014., str. 96 - 97.

Usput, prijevodi nekih drugih pojmova u ovoj publikaciji zaslužuju dodatno propitivanje. Primjerice, policy makers se prevodi kao stvaratelji politika. Trebalo bi provesti ozbiljnu znanstvenu raspravu, uključujući i stručnjake za hrvatski jezik te se usuglasiti o prevođenju ovog i drugih pojmova, koji bi, u ovom slučaju, odražavali značenje glagola make. Duhu hrvatskoga jezika ovdje je prikladan pojam izrađivači politika. $\mathrm{Na}$ izazove prevođenja latinskog pojma facit u hrvatskim prijevodima Biblije, što odgovara našem pojmu učiniti (engleskom make) upozorava Radoslav Katičić, op. cit. u bilj. 7, str. 234. Dok facit stoji ili se promatra sam za sebe, prevodi ga se s učiniti, međutim, u sklopu kojega izraza može se prevoditi i drukčije. Katičić zaključuje kako je prirodniji Rupčićev prijevod priredi svadbu, od Katančićevog učini svadbu.

78 Vidi više na: http://www.sgi-network.org/ (15. lipnja 2020.). 
(u predstavljanju rezultata javnosti najčešće se upotrebljavao pojam održivo upravljanje). U izvješću za 2019. godinu ističe se kako je hrvatska javna uprava visoko centralizirana i fragmentirana, često s nejasnom podjelom nadležnosti između središnje i lokalnih vlasti. Petak, Bartlett i Bönker ističu kako se ne provode reforme koje bi unaprijedile kvalitetu vladavine. Politizacija državnih službi i slabe strukture vladavine dovele su do klijentelizma u institucijama i zarobljenosti regulativom. ${ }^{79}$

Općenito, u Hrvatskoj su dvojbeni i relativno skromni kapaciteti države za oblikovanje i provedbu javnih politika. U tom kontekstu Z. Petak ističe skromne hrvatske upravljačke kapacitete vladavine, a njih se analizira putem četiri relevantna faktora: uloge strateškog planiranja, policy koordinacije, izrade politike na temelju dokaza i uloge društvenih konzultacija ${ }^{80}$ Kotarski i Petak zaključuju da među članicama EU-a Hrvatska ima najniže kapacitete za vladavinu, a to se povezuje i s nedostatcima glede kvalitete institucija. ${ }^{81}$

Komparativna analiza urbane i socijalne vladavine u europskim gradovima, prema istraživanjima Brandsena i suradnika, upozorila je na znatne razlike $\mathrm{u}$ dosezima tih praksi, a posebno u gradovima novih članica. ${ }^{82}$ Ključna je promjena u razvoju koncepta vladavine prijelaz s paternalizma države prema izgradnji kapaciteta dionika. Gradovi u slabije razvijenim zemljama, među njima i Hrvatskoj, nemaju potrebnu razinu socijalnog kapitala kao oslonca za razvoj inovativnih praksi vladavine kako bi se nosili s novim socijalnim rizicima te tako doprinijeli jačanju lokalne socijalne kohezije.

Prema Bežovanu i Matančević longitudinalna istraživanja razvoja kombinirane socijalne politike u Hrvatskoj, kao okvira za razvoj dobre vladavine, pokazuju napredak u kojem je sve prepoznatljivija uloga organizacija civilnog

79 Vidi više: Petak, Z.; Bartlett, W.; Bönker, F., Croatia Report-Sustainable Governance Indicators 2019, Bertelsmann Stiftung, Gütersloh, 2019., https:/www.sgi network.org/ docs/2019/country/SGI2019_Croatia.pdf(15. travnja 2021.).

80 Vidi: Petak, Z., Policy-Making Context and Challenges of Governance in Croatia, u: Petak, Z.; Kotarski, K. (ur.), Policy-Making at the European Periphery: The Case of Croatia, Palgrave Macmillan, Cham, 2018., str. 29 - 45.

81 Opširnije u: Kotarski, K.; Petak, Z., Croatia's Post-communist Transition Experience: The Paradox of Initial Advantage Turning into a Middle-Income Trap, u: Petak, Z.; Kotarski, K. (ur.), Policy-Making at the European Periphery: The Case of Croatia, Palgrave Macmillan, Cham, 2019., str. 1 - 25.

82 Opširnije u: Brandsen, T.; Cattacin, S.; Evers, A.; Zimmer, A. (ur.), Social Innovations in the Urban Context, Springer, Cham, Heidelberg, New York, Dordrecht i London, 2016. U ovoj knjizi su rezultati prethodno spomenutog FP7 WILCO projekta, a među 20 europskih gradova bili su uključeni Zagreb i Varaždin. 
društva i bolja suradnja svih dionika. ${ }^{83}$ Pokazuje se kako je moguće senzibilizirati javnost, mobilizirati dodatne resurse, razviti mreže, pokrenuti građane koji sve više volontiraju te ostvariti suradnju s relevantnim dionicima. Od lokalne do nacionalne razine pojavljuju se organizacije civilnog društva kao suvladari i predvodnici inicijativa kojima se proširuje prostor dobre vladavine. Organizacije civilnog društva pokazuju više optimizma i prepoznaju raznovrsnije resurse koje je moguće mobilizirati na lokalnim razinama. Članovi njihovih upravnih odbora, za razliku od članova upravnih vijeća državnih i privatnih ustanova, aktivni su, jačaju povjerenje i doprinose razvoju organizacija. Mediji se pokazuju kao dvojben dionik u procesima jačanja dobre vladavine, njih zanimaju uglavnom skandali, a manje su zainteresirani za primjere dobre prakse.

$\mathrm{Na}$ dnevnom redu naprednijih lokalnih i regionalnih zajednica jesu prikupljanje dokaza o izazovima socijalnog i gospodarskog razvoja, javna rasprava te izrada učinkovitijih i djelotvornijih socijalnih programa. S druge strane, snažna protuteža tom procesu su činjenice da su ravnateljstva i upravna vijeća u javnim ustanovama i dalje uglavnom kolonizirana pripadnicima političkih stranaka koji često ne ispunjavaju formalne uvjete za ravnateljska mjesta, odnosno za članstva u tim tijelima. Centrima za socijalnu skrb i zavodima za zapošljavanje, kao ključnim lokalnim socijalnim ustanovama, još se previše centralizirano upravlja. Osim toga, potrebno je povećati njihove stručne kapacitete te stalno ulagati u stjecanja novih znanja i vještina. Bolja tehnička opremljenost te veći i prikladniji uredski prostori povećali bi njihovu učinkovitost. Često stručno osoblje u gradovima, županijama i ministarstvima nema dovoljno znanja i vještina kako bi bilo zagovornik, predvodnik, koordinator ili pouzdan partner u programima inovativne socijalne politike. ${ }^{84}$

U širem društvenom kontekstu, Baturina i Babić ističu razvijeni koncept vladavine s primjerenom količinom socijalnog kapitala, obilježen participacijom relevantnih dionika, kao plodno tlo za nastanak socijalno poduzetničkih pothvata, čija je svrha ostvariti pozitivan društveni učinak..$^{85}$

Teme korporativne vladavine zaokupljaju pozornost naših istraživača već duže od dvadeset godina. U drugoj polovini 90 -ih godina 20. stoljeća D. Čengić analizira korporacijsko upravljanje u postprivatizacijskom razdoblju tranzicijskih zemalja te ističe kako "korporacijsko upravljanje u najširem smislu riječi može-

83 Opširnije u: Bežovan, G.; Matančević, J., Civilno društvo i pozitivne promjene, Školska knjiga, Zagreb, 2017.

84 Bežovan; Matančević, op. cit. u bilj. 83.

85 Vidi: Baturina, D.; Babić, Z., Socijalna ekonomija i socijalno poduzetništvo, Pravni fakultet Sveučilišta u Zagrebu, Zagreb, 2021. 
mo shvatiti kao sustav pomoću kojega vlasnici nekoga poduzeća prate rezultate rada unajmljenih menadžera kako bi osigurali da poduzeće bude efikasno, profitabilno i da se na taj način maksimalizira bogatstvo vlasnika." 86 Drugo Čengićevo opsežno istraživanje pokazuje kako politička elita i dio poslovne javnosti još uvijek nedovoljno pozornosti posvećuju problemima korporativnog upravljanja, međutim, jača svijest da nešto treba mijenjati glede upravljanja velikim dioničkim društvima. ${ }^{87}$

D. Tipurić i njegov tim sustavno se bave temom korporativnog upravljanja i ne dvoje o prijevodu pojma corporative governance, pa se o ovom pojmu kaže: "Korporativno upravljanje se može definirati kao sustav nadzornih mehanizama kojima svi dobavljači krucijalnih inputa trebaju osigurati povrate na svoja ulaganja u korporaciji, ne ugrozivši njezin dugoročni opstanak i prosperitet. Ono treba stvoriti okvir za postavljanje najvažnijih ciljeva, određivanje sredstava za njihovo postizanje i praćenje izvedbe te djelotvornosti njihova ostvarivanja." ${ }^{8}$ U drugoj studiji Tipurić zaključuje da je korporativno upravljanje svojevrsni "menadžment menadžmenta". 89

Teme koje u najširem smislu određuju prakse korporacijskoga upravljanja u različitim zemljama Tipuriću daju odgovore na pitanja: tko i zašto nadzire korporacije, kako se korporacijom upravlja i u čijem je to interesu; tko i na koji način treba nadzirati korporaciju; kakvi su odnosi vlasnika i menadžera te većinskih i manjinskih dioničara; na koji se način štite prava manjinskih dioničara; kako se korporacija odnosi prema javnosti i potencijalnim ulagačima; kako se u korporacijske poslove uključuju druge interesno-utjecajne skupine te kako se štite njihova prava i razmatraju zahtjevi; kako se iskazuje društvena odgovornost poduzeća. ${ }^{90}$

Provedeno istraživanje Tipurića i suradnika 2014. godine glede ocjena kvalitete korporativnog upravljanja mjereno je SEECGAN metodologijom, a indeks se izračunao na temelju odgovora na 98 pitanja grupiranih u sedam područja korporativnog upravljanja: struktura i upravljanje odborom; prava dioničara;

86 Čengić, D., Problemi korporacijskog upravljanja u postprivatizacijskom razdoblju, Društvena istraživanja, vol. 7, br. 6, 1998., str. 768.

87 Više vidi: Čengić, D., Vlasnici, menadžeri i kontrola poduzeća - Prilog analizi korporacijskog upravljanja u Hrvatskoj, Institut društvenih znanosti "Ivo Pilar", Zagreb, 2001., str. 152.

88 Tipurić, D. (ur.), Korporativno upravljanje, Sinergija, Zagreb, 2008., str. V.

89 Opsežnije u: Tipurić. D. i sur., Korporativno upravljanje u Hrvatskoj - Ocjena kvalitete korporativnog upravljanja hrvatskih dioničkih društava SEECGAN metodologijom, CIRU, Zagreb, 2015., str. 9.

90 Tipurić, op. cit. u bilj. 88. 
transparentnost i objava informacija; revizija i interna kontrola; naknade i nagrađivanja; upravljanje rizicima i društveno odgovorno poslovanje. Rezultati istraživanja govore da praksa korporativnog upravljanja u Hrvatskoj nije na zadovoljavajućoj razini. Segment naknade i nagrađivanja najlošije je ocijenjen segment korporativnog upravljanja. ${ }^{91}$

Analizirani hrvatski radovi glede teme vladavine pripadaju različitim istraživačkim disciplinama. Za upravnu znanost relevantna istraživačka područja su reforme javne uprave, decentralizacija, upravljanje gradovima, razvoj lokalne i mjesne samouprave kao i višerazinske vladavine. Osim toga, u analiziranim radovima ova disciplina se bavi konceptualizacijom dobre vladavine te utjecajem EU-a na ove procese kao i ulogom građana i civilnog društva. Kreiranje javnih politika i donošenja javnih odluka, održivost koncepata vladavine te upravljački kapaciteti vladavine važan su dio tema kojima se bave politološki radovi. Priprema i provedba programa, uloga civilnog društva, izgradnja socijalnog kapitala kao pretpostavki socijalno inovativnih praksi uz potrebnu razinu povjerenja teme su u okviru socijalne politike. Sociologija i ekonomija ponajviše se bave različitim aspektima vladavine u tvrtkama.

Koncepti vladavine, odnosno upravljanja, teme su programa visokoškolske nastave, a cilj im je, primjerice, “... razumjeti koncept višestupanjskog upravljanja (multi-level governance) koji pomaže shvaćanju suvremenih upravnih procesa (društvena uklopljenost javne uprave)"92, odnosno kao jedan od ishoda učenja navodi se: "U najširem smislu vladavinu (governance) interpretirati kao kontinuirani politički proces postavljanja jasnih ciljeva društva i intervencije $u$ iste radi njihova ostvarivanja." 93 Vladavina se tematizira i na međunarodnom združenom doktorskom studiju. ${ }^{94}$ Očekivalo bi se da je različito prevođenje pojma governance već potaknulo rasprave.

Dakle, analizirani radovi dobro oslikavaju pluralno i kompleksno značenje pojma governance. Međutim, ako se ovaj pojam prevodi kao upravljanje, a uprav-

91 Tipurić i sur., op. cit. u bilj. 89, str. 231.

$92 \mathrm{Na}$ Pravnom fakultetu u Zagrebu predaje se kolegij Višestupanjska uprava i regionalna uprava, https://www.pravo.unizg.hr/UZ/predmeti (15. travnja 2021.).

$93 \mathrm{Na}$ Pravnom fakultetu u Osijeku predaje se kolegij Konstitucionalno oblikovanje višestupnjevane dobre vladavine, https:/www.pravos.unios.hr/katedra-ustavnih-i-politickih-znanosti/konstitucionalno-oblikovanje-visestupnjevane-vladavine (15. travnja 2021.).

$94 \mathrm{Na}$ Pravnom fakultetu u Zagrebu provodi se Međunarodni združeni doktorski studij Ljudska prava, društvo i višerazinska vladavina (Human Rights, Society, and Multi-level Governance), https://www.pravo.unizg.hr/studij/doktorski-pravni?@=8etl (15. travnja 2021.). 
ljanje poglavito znači da netko naređuje i kontrolira, onda je dovedeno u pitanje značenje pojma governance.

\section{PREVOĐENJE I ZNAČENJE NEKIH DRUGIH POJMOVA}

Dakle, u kontekstu analize prevođenja pojma governance i zagovaranja pojma vladavina naspram pojma upravljanje, pred hrvatskim jezikom su civilizacijski izazovi prevođenja niza pojmova koji osobito dolaze na dnevni red našim članstvom u EU-u. U skladu sa svrhom rada naslovljavaju se izazovi prevođenja još nekih često korištenih pojmova.

Početkom 90-ih godina 20. stoljeća na dnevni red javnih rasprava i istraživanja u društvenim znanostima dolazi tema civilnog društva. Pojam civil society $\mathrm{u}$ početku se $\mathrm{u}$ nas prevodi i kao građansko društvo ${ }^{95}$, dok se, primjerice, $\mathrm{u}$ susjednoj Sloveniji o tome nije dvojilo, već se koristi pojam civilna družba. Duže je trebalo za uključivanje u međunarodne istraživačke projekte kojima se činjenično opisivalo i mjerilo razvijenost civilnog društva, nakon čega se prešlo na upotrebu pojma civilno društvo. ${ }^{96}$

Pojam welfare state u Hrvatskoj se dugo uglavnom prevodio kao država blagostanja. Stasanjem i akademizacijom socijalne politike kao relevantnog područja istraživanja i visokoškolske nastave u 90-ima sve veći dio akademske zajednice taj pojam prevodi kao socijalna država. Pojam država blagostanja sugerira izvjesno obilje u kojem nitko ne oskudijeva, s druge strane socijalna država, pojam nastao pod njemačkim utjecajem, odnosno pod utjecajem koncepta socijalno-tržišnog gospodarstva, sugerira određene naknade socijalno ugroženim skupinama. ${ }^{97}$

Trebalo je neko vrijeme da se udomaći u akademskoj zajednici, a i u javnosti prevođenje pojma stakeholder kao dionik. S druge strane, SWOT analiza, široko rasprostranjeni alat, prvi znak strengths prevodi kao snagu, a ne kao jakost. Očito,

95 Vidi: Riedel, M. (ur.), Građansko društvo i država: povijest razlike i nove rasprave, Naprijed, Zagreb, 1991.

96 Bežovan, op. cit. u bilj. 42.

97 Klasična literatura o tipologiji socijalnih država govori o njihovoj ukorijenjenosti u tradiciju svakog društva, a one se razlikuju, prije svega, po razini socijalnih prava i uvjetima za njihovo ostvarenje. U tom smislu britanska welfare state kao liberalni socijalni režim znatno je manje izdašna od njemačke konzervativno korporativističke Sozialstaat. Više vidi: Esping-Andersen, G., The Three Worlds of Welfare Capitalism, Princeton University Press, Princeton, New Jersey, 1990. Dakle, liberalna, konzervativno-korporativistička i socijaldemokratska socijalna država različiti su realiteti socijalnih režima. Isto tako, francuski pojam l'État-providence treba prevoditi kao socijalna država. 
jednom površno prevedeni pojmovi se ukorjenjuju i bez propitivanja prenose na nove generacije.

U europskim dokumentima, razvojnim strategijama i u propisima još se nepravilno prevodi pojam affordability. Znakovit je primjer iz Operativnog programa Učinkoviti ljudski potencijali, u kojemu se određeni prioritet engleske inačice: Enhancing access to affordable, sustainable and high quality services, including health care and social services of general interest. ${ }^{98}$ prevodi kao "Poboljšanje pristupa pristupačnim, održivim i visokokvalitetnim uslugama, uključujući usluge zdravstvene skrbi i socijalne usluge od općeg interesa." ${ }^{99}$ Naime, pojam affordability treba prevoditi kao priuštivost. Da bi si priuštili zdravstvene ili socijalne usluge, građani ih trebaju platiti ili dijelom ili u cijelosti. Građani imaju problema s pristupačnošću takvih usluga jer su im one udaljene. Koncept priuštivosti središnja je socijalnopolitička tema $\mathrm{u}$ istraživanjima podmirivanja stambenih potreba. ${ }^{100}$

Pojmovi social entrepreneurship i social economy također su na dnevni red došli pridruživanjem Europskoj uniji. U strategiji koja je izrađena za to područje razvoja upotrebljavaju se pojmovi društveno poduzetništvo i društvena ekonomija. ${ }^{101} \mathrm{U}$ raspravi nisu prihvaćeni argumenti da se tim tipom aktivnosti prije svega ostvaruju određeni socijalni ciljevi, pomoć slabijima i njihova socijalna integracija, a to su argumenti za određene porezne povlastice koje im država treba dati radi razvoja takvih aktivnosti. Zanemarivano je, primjerice, i slovensko nazivlje u kojem je za razvoj tih djelatnosti donesen i Zakon o socijalnim poduzećima. ${ }^{102} \mathrm{~K}$ tome, rečenom strategijom predviđeno je i donošenje Zakona o društvenim poduzećima, a nije se bilo svjesno činjenice da je 1991. godine bio donesen Zakon o pretvorbi društvenih poduzeća, kako su se ona zvala u doba socijalizma.

Često upotrebljavan pojam u dokumentima EU-a je eligibility, koji se službeno prevodi kao prihvatljivost. Primjerice, prema kriterijima raspisanog natječaja

98 Operational Programme Efficient Human Resources 2014-2020, https://ec.europa.eu/regional_policy/en/atlas/programmes/2014-2020/croatia/2014hr05m9op001, str. 25 (15. travnja 2021.). Vidi: Petak, op. cit. u bilj. 68.

99 Operativni program Učinkoviti ljudski potencijali 2014. - 2020., http://arhiva.strukturnifondovi.hr/UserDocsImages/Documents/Strukturni\%20fondovi\%202014.\%20 \%E2\%80\%93\%202020/OPULJP\%20hr\%2020150709.pdf, str. 23 (15. travnja 2021.).

100 Vidi: Projekt RE-DWELL - Delivering affordable and sustainable housing in Europe, Marie Curie, Obzor 2020., http://www.re-dwell.eu/ (15. rujna 2021.).

101 Vidi: http://www.esf.hr/wordpress/wp-content/uploads/2015/02/Strategija-razvoja-dru\%C5\%Altvenog-poduzetni\%C5\%Altva-u-RH-za-razdoblje-2015-2020.pdf (18. studenoga 2020.).

102 Više vidi: https://www.ora.si/index.php/socialno-podjetnistvo/ (17. studenoga 2020.). 
prihvatljivi (eligible) su određeni projekti ili aktivnosti kojima će se oni baviti. Međutim, u prevođenju pojma prihvatljiv s hrvatskog na engleski očekivano bismo imali pojam acceptable. Dakle, pojam eligible označava da su u odnosu na zadane kriterije na natječaju naši projekti s konkretnim aktivnostima izberivi ${ }^{103}$, odnosno da udovoljavaju potrebnim uvjetima da budu odabrani.

Pojam resilience u širokoj je upotrebi u akademskoj literaturi, a u novije vrijeme i u dokumentima EU-a. Pojam se dominantno prevodi kao otpornost, što je odgovarajući prijevod za pojam resistant. Pojam pruživ (resilient) ${ }^{104}$ označava kapacitete pojedinaca, zajednica, institucija, poslovnih subjekata i sustava grada da se prilagode, prežive i napreduju bez obzira na to kakvom kroničnom stresu ili akutnom šoku bili izloženi. Primjerice, pruživi gradovi podnose, spremno odgovaraju i prilagođavaju se opterećenjima i šokovima koji se javljaju. Prema projektu Rockefellerove zaklade četiri su dimenzije urbane pruživosti. ${ }^{105}$

$\mathrm{Na}$ razliku značenja pojmova otpornosti i pruživosti upozorava Green. ${ }^{106}$ Otpornost podrazumijeva sposobnost: osporiti napad i učinak katastrofe; nastaviti raditi blizu normalnog kapaciteta i sposobnosti; nastaviti s normalnim radom uz minimalan poremećaj te pobijediti učinak događaja. S druge strane, pruživost podrazumijeva sposobnost apsorbiranja učinka katastrofe; dostojanstveno podnijeti degradaciju učinka; sve na takav način da se možemo vratiti u normalne operacije s najmanjim mogućim kašnjenjem i najmanje mogućim disfunkcijama te ograničiti učinak događaja.

S takvim opisom značenja tih pojmova moguće je razumjeti sintagmu: $R e$ sistance, Resilience, and Recovery: Patient Care in a Pandemic ${ }^{107}$ te se složiti s tim da

103 Bujas, Ž., Veliki englesko-hrvatski rječnik, četvrto izdanje, Nakladni zavod Globus, Zagreb, 2008., str. 273. U rječniku taj pojam prevodi se kao: izberiv, podesan, podoban, prihvatljiv, poželjan, kvalificiran, koji udovoljava uvjetima; koji pripada pod. Objašnjenje značenja u engleskom jeziku: https://www.collinsdictionary.com/dictionary/english/eligible (15. travnja 2021.).

104 Bujas, op. cit. u bilj. 103, str. 749. Taj se pojam prevodi kao: pruživ, elastičan; žilav, otporan. Onaj koji je resilient, znači da se brzo oporavlja od nesreće. Objašnjenje značenja u engleskom jeziku: https:/www.collinsdictionary.com/dictionary/english/ resilient (15. travnja 2021.).

105 Vidi: http://www.100resilientcities.org/what-is-the-100-resilient-cities-platform-ofpartners/\#/-_Yz46OTgyNSdpPTEocz5j/ (15. travnja 2021.).

106 Vidi: Green, G. W., Resistance and resilience - Some basic postulates, 2008., https://slideplayer.com/slide/9150126/ (15.veljače 2020).

107 Vidi: https://www.ifm.org/learning-center/resistance-resilience-and-recovery-patientcare-in-a-pandemic/ (17. studenoga 2020.). 
pojam resilience ${ }^{108}$ ne znači otpornost, pa onda tragati za ogovarajućim pojmom na hrvatskom jeziku uzimajući u obzir i predloženi. ${ }^{109}$

\section{ZAKLJUČAK}

Hrvatska akademska zajednica očito nije dovoljno osjetljiva na prevođenje pojmova koji u ovim vremenima dolaze iz engleskog jezika. Pojmovi, a i cijeli tekstovi, prevode se "knjiški", a da se pritom ne pita za njihovo stvarno značenje i razumijevanje u društvenim pojavama i činjenicama. Tako se "prijevodi" pojmova uvode u procese obrazovanja bez prethodne rasprave u akademskim krugovima ili bez upozorenja na to da u vezi s prijevodom postoje drukčije prakse. Pojmovi se često upotrebljavaju "zdravo za gotovo" u javnim dokumentima, propisima te u javnom diskursu.

Pojmovi imaju određeno značenje u odnosu na druge pojmove s kojima se koriste u opisivanju društvene stvarnosti ili ideja kojima bi se ta stvarnost mogla reformirati, pa učiniti boljom i poželjnijom. U tom smislu postavlja se zahtjev artikulacije, dovođenja različitih pojmova u smisleni odnos tako da oni funkcioniraju zajedno, a da onda korisnici takvih informacija mogu pouzdano razlučiti o čemu je riječ.

Prevođenje pojma governance kao upravljanje ne odražava značenje, a ni smisao toga pojma. Upravljanje se provodi odozgo nizom upravnih pravila i smjernica te kontrolom, a najčešće djelovanjem institucija javne uprave. U tom procesu dominiraju stručnjaci odgovorni za pružanje usluga. U tom smislu upravljanje je "stari" pojam i stručnoj javnosti poznate su društvene činjenice koji on opisuje. Međutim, governance treba prevoditi etimološki kao vladavinu koja podrazumijeva djelovanje odozdo s dionicima u horizontalnoj razini, pripravnim na suradnju, pri čemu se njeguju načela samoorganizacije i umrežavanja. Suvremeni izazovi pritišću vlasti na različitim razinama i one su sve svjesnije kako se s takvim izazovima moguće nositi tek suradnjom s ostalim dionicima u pripremi programa, donošenju odluka i u njihovoj provedbi, a izvršne se vlasti svrstavaju u mrežu dionika čineći koncept vladavine. Dakle,

108 Izvorni govornik engleskog jezika s visokoškolskom naobrazbom svjedoči kako taj pojam "para uši" prosječnim građanima, a mnogi s prosječnom naobrazbom ne mogu dokučiti što on zapravo znači.

109 Primjerice, u radu Suryanto, H. I.; Handoyo, S., Family Resilience: A Conceptual Review, Advances in Social Science, Education and Humanities Research, br. 133, 2018., str. 42 - 48, pokazuje se kako obitelji mogu biti resistant i resilient na krizu, pa u tom smislu te pojmove treba i različito prevoditi. 
vladavina je novi pojam ${ }^{110}$, fluidan i heterogenog značenja, koji proizlazi iz suodnosa umreženih dionika. Takvo razumijevanje jasno razlučuje značenje sintagme governance and public administration, pa time razvijen koncept vladavine, kao mreže dionika, može doprinijeti boljem procesu izrade javnih politika ili mobiliziranju dodatnih resursa, a javna uprava je tu kako bi, prije svega, pružala usluge građanima i poslovnom sektoru. Između tih dvaju koncepata postoji višestruka interakcija.

Većina prije spomenutih razvojnih dokumenata ne opisuje na odgovarajući način koncepte vladavine. Radi njihova približavanja donositeljima odluka i provoditeljima programa valjalo bi ih dopuniti, navodeći i primjere dobre prakse. U tom kontekstu višestruko bi bio koristan narativ, primjerice, dobre vladavine s primjerima iz domaćeg iskustva, napisan jetkom akademskom esejistikom.

Empirijska istraživanja u ovom području su nedostatna, a njihova pomoć u prepoznavanju i analiziranju primjera dobre prakse, osobito inovacija u području vladavine, mogao bi biti put prema jačanju pripravnosti vladavine. U temelju pristupa su zahtjevi za građanskom participacijom kao imperativ modernizacije i europeizacije planiranja budućnosti. Učinkovitost vladavine uvelike će ovisiti o razini povjerenja građana $u$ institucije te razini povjerenja među institucijama. Takva orijentacija može doprinijeti i izgradnji kapaciteta za povlačenje i svrhovito ulaganje sredstava EU-a te jačanju konvergencijskih procesa.

Glede ostalih pojmova, affordability znači priuštivost, a pristupačnost, kojim se sada uglavnom prevodi u službenim dokumentima, ima drugo značenje. Tako se od nekih programa može tražiti da budi priuštivi i pristupačni. Neodgovarajuće prevođenje pojma eligible vodi jezičnom siromaštvu. Socijalno poduzetništvo i socijalna ekonomija dio su socijalne politike, pa njihovi prijevodi kao "društveni” ne trebaju podsjećati na vrijeme socijalizma. Isto tako, resilience ne znači otpornost, pa ćemo traganjem za odgovarajućim pojmom u dijaloškom pristupu potvrditi svoje civilizacijske kompetencije.

\section{LITERATURA}

Anheier, K. H., Governance: What Are the Issues?, u: Hertie School of Governance, The Governance Report 2013, Oxford University Press, Oxford, 2013., str. 11-32. Anheier, K. H., Nonprofit Organizations. Theory, Management, Policy, Routledge, London, New York, 2014.

110 Osborne, op. cit. u bilj. 6, str. 381 . 
Anheier, K. H., On the Future of the Public Policy School, Global Policy, vol. 10, br. 1, 2018., str. 75-83, doi: 10.1111/1758-5899.12599

Anheier, K. H.; Abels, M. C., Corporate Governance in Comparative Perspectives, u: Anheier, K. H.; Baums, T. (ur.), Advances in Corporate Governance: Comparative Perspectives, Oxford University Press, Oxford, 2020., str. 1-9.

Anheier, K. H.; Abels, M. C., Corporate Governance: What are the Issues?, u: Anheier, K. H.; Baums. T. (ur.), Advances in Corporate Governance: Comparative Perspectives, Oxford University Press, Oxford, 2020., str. 10-42.

Anheier, K. H.; Kaufmann, S.; Ziaja, S., Ten Years After: The Global Financial and Economic Crisis - Impact and Implications, u: Hertie School of Governance, The Governance Report 2018, Oxford University Press, Oxford, 2018., str. 13-28.

Bađun, M., Governance i javna uprava u kontekstu pridruživanja Hrvatske Europskoj uniji, u: Ott, K. (ur.), Pridruživanje Hrvatske Europskoj uniji: Izazovi institucionalnih prilagodbi, Institut za javne financije i Zaklada Friedrich Ebert, Zagreb, 2004., str. 125-157.

Baturina, D.; Babić, Z., Socijalna ekonomija i socijalno poduzetništvo, Pravni fakultet Sveučilišta u Zagrebu, Zagreb, 2021.

Bežovan, G., Civilno društvo, Nakladni zavod Globus, Zagreb, 2004.

Bežovan, G., Final Conference of the Connex Network of Excellence: Efficient and Democratic Governance in a Multilevel Europe, Revija za socijalnu politiku, vol. 15, br. 2, 2008., str. 290-293.

Bežovan, G.; Matančević, J., Civilno društvo i pozitivne promjene, Školska knjiga, Zagreb, 2017.

Bežovan, G.; Zrinščak, S., Civilno društvo u Hrvatskoj, Naklada Jesenski i Turk i Hrvatsko sociološko društvo, Zagreb, 2007.

Bozzini, E.; Enjolras, B. (ur.), Governing Ambiguities: New Forms of Local Governance and Civil Society, Nomos, Baden-Baden, 2012.

Brandsen, T.; Cattacin, S.; Evers, A.; Zimmer, A. (ur.), Social Innovations in the Urban Context, Springer, Cham, Heidelberg, New York, Dordrecht, London, 2016.

Bujas, Ž., Veliki englesko-hrvatski rječnik, četvrto izdanje, Nakladni zavod Globus, Zagreb, 2008.

Čengić, D., Problemi korporacijskog upravljanja u postprivatizacijskom razdoblju, Društvena istraživanja, vol. 7, br. 6, 1998., str. 767-792.

Čengić, D., Vlasnici, menadžeri i kontrola poduzeća - Prilog analizi korporacijskog upravljanja u Hrvatskoj, Institut društvenih znanosti Ivo Pilar, Zagreb, 2001. 
Đulabić, V., Regionalizam i regionalna politika, Društveno veleučilište u Zagrebu, Zagreb, 2007.

Esping-Andersen, G., The Three Worlds of Welfare Capitalism, Princeton University Press, Princeton, New Jersey, 1990.

Europska komisija, Europska vladavina - bijela knjiga, Revija za socijalnu politiku, vol. 12, br. 2, 2005., str. 189-213.

Franzen, A.; Hobma, F.; de Jonge, H.; Wigmans, G. (ur.), Management of Urban Development Processes in the Netherlands - Governance, Design, Feasibility, Techne Press, Amsterdam, 2011.

Green, G. W., Resistance and resilience - Some basic postulates, 2008., https://slideplayer.com/slide/9150126/

Guardo, J., A Multi Sectoral Approach to Funding and Finance, webinar "FUNDING. Multiple Funding Sources as the Key for Integration and Sustainability" UDN webinar series 'Six Building Blocks to Sustainable Urban Development' based on the Handbook of Sustainable Urban Development Strategies, https://udn-handbook. tw.events/ (25. studenoga 2020.).

Hopt, J. K., Corporate Governance von Finanzinstituten: Empirische Befunde, Theorie und Fragen in den Rechts- und Wirtschaftswissenschaften, Zeitschrift für Unternehmens- und Gesellschaftsrecht, vol. 46, br. 4, 2017., str. 438-459.

Katičić, R., Novi jezikoslovni ogledi, Školska knjiga, Zagreb, 1986.

Kohler-Koch, B.; Eising, R. (ur.), The Transformation of Governance in the European Union, Routledge, London, New York, 2005.

Koprić, I., Contemporary Croatian Public Administration on the Reform Waves, Godišnjak Akademije pravnih znanosti Hrvatske, vol. 2, br. 1, 2011., str. 1-40.

Koprić, I., Decentralizacija i dobro upravljanje gradovima, Hrvatska javna uprava, vol. 9, br. 1, 2009., str. 69-78.

Koprić, I., Suvremeni trendovi u razvoju lokalne samouprave i hrvatska lokalna i regionalna samouprava, u: Koprić, I. (ur.), Europeizacija hrvatske lokalne samouprave: dva desetljeća primjene standarda Europske povelje o lokalnoj samoupravi, Institut za javnu upravu, Zagreb, 2018., str. 1-56.

Koprić, I.; Musa, A.; Giljević, T. (ur.), Građani, javna uprava i lokalna samouprava: povjerenje, suradnja, potpora, Institut za javnu upravu, Zagreb, 2017.

Kotarski, K.; Petak, Z., Croatia’s Post-communist Transition Experience: The Paradox of Initial Advantage Turning into a Middle-Income Trap, u: Petak, Z.; Kotarski, K. (ur.), Policy-Making at the European Periphery: The Case of Croatia, Palgrave Macmillan, Cham, 2019., str. 1-25. 
Lebrun, M., Multilevel governance as way towards a more involved and accountable political union, European View, vol. 13, 2014., str. 327-332, doi:10.1007/ s12290-014-0320-8

Levi-Faur, D., From "Big Government” to "Big Governance”?, u: Levi-Faur, D. (ur.), The Oxford Handbook of Governance, Oxford University Press, Oxford, 2012., str. 3-18.

Lodge, M.; Wegrich, K., Enhancing Administrative Capacities for Better Governance: Seven Recommendations, $\mathrm{u}$ : Hertie School of Governance, The Governance Report 2014, Oxford University Press, Oxford, 2014., str. 151-170.

Lodge, M.; Wegrich, K., Setting the Scene: Challenges to the State, Governance Readiness, and Administrative Capacities, u: Hertie School of Governance, The Governance Report 2014, Oxford University Press, Oxford, 2014., str. 15-26.

Manojlović Toman, R.; Vukojičić Tomić, T.; Koprić, I., Neuspješna europeizacija hrvatske mjesne samouprave: nedovoljna atraktivnost ili loše institucionalno oblikovanje, Godišnjak Akademije pravnih znanosti Hrvatske, vol. X, br. 1, 2019. str.185-210.

Ministarstvo rada, mirovinskog sustava, obitelji i socijalne politike, Vrednovanje djelotvornosti, učinkovitosti i učinka Operativnog programa Učinkoviti ljudski potencijali 2014.-2020., 2021., http://www.esf.hr/wordpress/wp-content/uploads/2021/07/ Zavrsno-izvjesce_evaluacija_Horizontalna_OPULJP_final_lipanj_2021.pdf (1.prosinca 2021.).

Miošić, N.; Bronić, M.; Škrabalo, M., Indeks dobrog upravljanja u Hrvatskoj 2012. GONG i Institut za javne financije, Zagreb, 2013.

Odbor regija, Povelja o višestupanjskom upravljanju u Europi, u: Koprić, I.; Škarica, M.; Milošević, B. (ur.), Suradnja i razvoj u lokalnoj i regionalnoj samoupravi, Institut za javnu upravu, Zagreb, 2014., str. 324-326.

OECD, OECD Principles of Corporate Governance, https://www.oecd.org/corporate/ ca/corporategovernanceprinciples/31557724.pdf

Operational Programme Efficient Human Resources 2014-2020, https://ec.europa.eu/ regional_policy/en/atlas/programmes/2014-2020/croatia/2014hr05m9op001

Operativni program Učinkoviti ljudski potencijali 2014.-2020., http://arhiva.strukturnifondovi.hr/UserDocsImages/Documents/Strukturni\%20fondovi\%20 2014.\%20\%E2\%80\%93\%202020/OPULJP\%20hr\%2020150709.pdf

Osborne, P. S., The New Public Governance?, Public Management Review, vol. 8, br. 3, 2006., str. 377-387, doi: 10.1080/14719030600853022

Perko-Šeparović, I., Uvod - pojam dobrog upravljanja i razvoja, u: Perko-Šeparović, I. (ur.), Priručnik za dobro upravljanje, Hrvatski pravni centar, Zagreb, 2006., str. $1-10$. 
Pestoff, V.; Brandsen, T.; Verschuere, B. (ur.), New Public Governance, the Third Sector and Co-Production, Routledge, New York, London, 2012.

Petak, Z., Dimenzije javnih politika i javno upravljanje, Politička misao, vol. 45, br. 2, 2008., str. 9-26.

Petak, Z., Javne politike i problemi modernog upravljanja, Hrvatska i komparativna javna uprava, vol. 8, br. 2, 2008., str. 443-462.

Petak, Z., Policy-Making Context and Challenges of Governance in Croatia, u: Petak, Z.; Kotarski, K. (ur), Policy-Making at the European Periphery: The Case of Croatia, Palgrave Macmillan, Cham, 2018., str. 29-45.

Petak, Z.; Bartlett, W.; Bönker, F., Croatia Report- Sustainable Governance Indicators 2019, Bertelsmann stiftung, Gütersloh, 2019., https:/www.sginetwork.org/ docs/2019/country/SGI2019_Croatia.pdf (15. travnja 2021.).

Petek, A.; Petković, K. (ur.), Pojmovnik javnih politika, Fakultet političkih znanosti, Sveučilište u Zagrebu, Zagreb, 2014.

Rentzsch, C., Everybody on Board? Opportunity Structures for Social Innovations in Münster, u: Brandsen, T.; Cattacin, S.; Evers, A.; Zimmer, A. (ur.), Social Innovations in the Urban Context, Springer, Cham, Heidelberg, New York, Dordrecht, London, 2016., str. 45-64.

Republic of Croatia, Partnership Agreement for the European Structural and Investment Funds in the EU Financial Period 2014-2020 - Stimulating Smart, Inclusive and Sustainable Growth, 2014., http://arhiva.strukturnifondovi.hr/UserDocsImages/ prijedlogpartnerskogsporazuma.pdf

Republika Hrvatska, Sporazum o partnerstvu između Republike Hrvatske i Europske komisije za korištenje EU strukturnih i investicijskih fondova za rast $i$ radna mjesta $u$ razdoblju 2014.-2020., https://razvoj.gov.hr/UserDocsImages//arhiva/EU\%20 fondovi/Programi\%20prekogranicna\%202

Rhodes, M., The Role of Social Pacts in European Socio-economic Governance, Policy Brief 34, 2008., http://www.eunewgov.org/database/PUBLIC/Policy_Briefs/ NEWGOV_Policy_Brief_no34.pdf

Rhodes, R. A. W., The New Governance: Governing Without Government, Political Studies, vol. 44, br. 4, 1996., str. 652-667, doi: 10.1111/j.1467-9248.1996. tb01747.x

Rhodes, R. A. W., Waves of Governance, u: Levi-Four, D. (ur.), The Oxford Handbook of Governance, Oxford University Press, Oxford, 2012., str. 33-48.

Riedel, M. (ur.), Građansko društvo i država: povijest razlike i nove rasprave, Naprijed, Zagreb, 1991.

Semantika, Hrvatska enciklopedija, mrežno izdanje. Leksikografski zavod Miroslav Krleža, 2021., https://www.enciklopedija.hr/natuknica.aspx?id=55330 
Sirovátka, T.; Winkler, J., Governance of Activation Policies in the Czech Republic: Uncoordinated Transformation, u: van Berkel. R.; de Graaf, W.; Sirovátka, T. (ur.), The Governance of Active Welfare States in Europe, Palgrave Macmillan, Basingstoke, 2011., str. 173-194.

Sørensen, E.; Torfing, J., Introduction. Governance Network Research: Towards a Second Generation, u: Sørensen, E.; Torfing, J. (ur.), Theories of Democratic Network Governance, Palgrave Macmillan, Basingstoke, 2007., str. 1-21.

Staing, P.; Kayser, A. M., Governance Indicators: Some Proposals, u: Anheier, K. H. (ur.), Governance Challenges and Innovations - Financial and Fiscal Governance, Oxford University Press, Oxford, 2013., str. 189-220.

Strategija razvoja javne uprave za razdoblje od 2015. do 2020. godine, Narodne novine, br. $70 / 2015$.

Strategija reforme državne uprave za razdoblje 2008.-2011., Hrvatska i komparativna javna uprava, vol. 8, br. 2, 2008., str. 315-342.

Suryanto, H. I.; Handoyo, S., Family Resilience: A Conceptual Review, Advances in Social Science, Education and Humanities Research, br. 133, 2018., str. 42-48, doi: 10.2991/acpch-17.2018.9.

Tipurić, D. (ur.), Korporativno upravljanje, Sinergija, Zagreb, 2008.

Tipurić. D. i sur., Korporativno upravljanje u Hrvatskoj - Ocjena kvalitete korporativnog upravljanja hrvatskih dioničkih društava SEECGAN metodologijom, CIRU, Zagreb, 2015.

Tosics, I., Integrated territorial investment - A missed opportunity?, u: Bachtler, J.; Berkowitz, P.; Hardy, S.; Muravska, T. (ur.), EU cohesion policy: reassessing performance and direction, Routledge, London, 2017., str. 284-296.

van Berkel, R.; de Graaf, W.; Sirovátka, T., The Governance of Active Welfare States, u: van Berkel, R.; de Graaf, W.; Sirovátka, T. (ur.), The Governance of Active Welfare States in Europe, Palgrave Macmillan, Basingstoke, 2011., str. 1-21.

van Heerden, S., Governance, u: Fioretti, C.; Pertoldi, M.; Busti, M.; van Heerden, S. (ur.), Handbook of Sustainable Urban Development Strategies, Publications Office of the European Union, Luxembourg, 2000., str. 90-125.

Vlada Republike Hrvatske, Strategija razvoja društvenog poduzetništva u Republici Hrvatskoj za razdoblje od 2015. do 2020. godine, 2015., http://www.esf.hr/ wordpress/wp-content/uploads/2015/02/Strategija-razvoja-dru\%C5\%Altvenog-poduzetni\%C5\%Altva-u-RH-za-razdoblje-2015-2020.pdf

Vlada Republike Hrvatske, Strategija regionalnog razvoja Republike Hrvatske za razdoblje do kraja 2020. godine, 2017., https://razvoj.gov.hr/UserDocsImages/O\%20 ministarstvu/Regionalni\%20razvoj/razvojne\%20strategije/Strategija\%20 
regionalnog\%20razvoja\%20Republike\%20Hrvatske\%20za\%20razdoblje\%20 do\%20kraja\%202020._HS.pdf

Vukojičić Tomić, T., Dobra vladavina: od konceptualizacije do realizacije, Politička misao, vol. 53, br. 2, 2016., str. 105-130.

Vukojičić Tomić, T.; Manojlović Toman, R., Role of the Sub-Municipal Government in Croatia - Learning from a Positive Experience, Review of European and Comparative Law, vol. 39, br. 4, 2019., str. 59-77, doi: 10.31743/recl.4783

Zeitlin, J.; Pochet, P.; Magnusson, L. (ur.), The Open Method of Coordination in Action: The European Employment and Social Inclusion Strategies, P.I.E.-Peter Lang, Bruxelles, 2005. 


\section{Summary}

\section{Gojko Bežovan*}

\section{WHAT DOES THE TERM GOVERNANCE MEAN AND HOW SHOULD IT BE TRANSLATED?}

The paper analyses the meaning and understanding of the term governance and its translation into Croatian. Governments, executive authorities, governing in a top-down approach, issuing orders, and controlling, administering, cannot effectively and efficiently deal with the problems and challenges. To meet such challenges, governments accept bottom-up governance, based on the horizontal principle of cooperation with other stakeholders, which enables them to mobilize available resources, build the trust and a new network of cooperation, and develop the concept of governance. The concept of good governance in the European Union is a tool that strengthens convergence processes. Research on the implementation of the concept of governance in Croatia is rare, and papers mainly analyse governance, good governance, and multilevel governance as a new administrative doctrine. Having in mind the meaning of the term governance in English, and its meaning in relation to other terms, it is held that it should be translated into Croatian as vladavina, not as upravljanje. In addition, the meaning of the terms: affordability, social entrepreneurship, eligibility, and resilience are analysed and the terms for their translation into Croatian are proposed.

Key words: governance, administration, good governance, translation into Croatian

* Gojko Bežovan, Ph. D., Professor, Faculty of Law, University of Zagreb, Trg Republike Hrvatske 14, 10000 Zagreb; gojko.bezovan@pravo.hr;

ORCID ID: orcid.org/0000-0002-7543-6875 